\title{
Convective Circulation During Differential Heating and Cooling in the Minky Creek Embayment of Guntersville Reservoir, Data Summary for 1991
}

Joint Agency

Guntersville Project

Aquatic Plant Management

prepared by

Craig S. Smith1, William F. James² and John W. Barko 1,3

1U.S. Army Engineer Waterways Experiment Station

3909 Halls Ferry Road

Vicksburg, Mississippi 39180

2U.S. Army Engineer Watenways Experiment Station,

Equ Galle Limnological Laboratory, P.O. Box 237

Spring Valley, Wisconsin 54767

3U.S. Fish \& Wildlife Service

Environmental Management Technical Center

575 Lester Avenue

Onalaska, Wisconsin 54650

Sponsored by

Tennessee Valley Authority and US Army Corps of Engineers

TVA/WM-93/14

June 1993

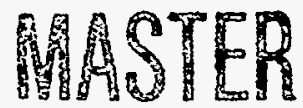

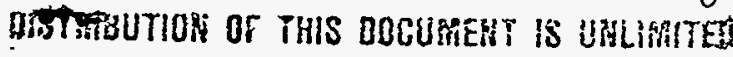




\section{DISCLAIMER}

This report was prepared as an account of work sponsored by an agency of the United States Government. Neither the United States Government nor any agency thereof, nor any of their employees, make any warranty, express or implied, or assumes any legal liability or responsibility for the accuracy, completeness, or usefulness of any information, apparatus, product, or process disclosed, or represents that its use would not infringe privately owned rights. Reference herein to any specific commercial product, process, or service by trade name, trademark, manufacturer, or otherwise does not necessarily constitute or imply its endorsement, recommendation, or favoring by the United States Government or any agency thereof. The views and opinions of authors expressed herein do not necessarily state or reflect those of the United States Government or any agency thereof. 


\section{DISCLAIMER}

Portions of this document may be illegible in electronic image products. Images are produced from the best available original document. 


\section{Preface}

The Joint Agency Guntersville Project (JAGP) is sponsored by the Tennessee Valley Authority (TVA) and the Headquarters, U.S. Army Corps of Engineers (HOUSACE). All JAGP activities are directed by the TVA, the U.S. Army Engineer Waterways Experiment Station (WES), and the U.S. Army Engineer District, Nashville (ORN).

The TVA Vector Plant Management Program, directed by Dr. Joseph C. Cooney and Aquatic Plant Management Program directed by Mr. A. Leon Bates, serve as lead programs for managing this project, with support from other organizations in TVA's Resource Group. Project funding is supported by Congressional appropriations to the TVA. The work is conducted under the management of Mr. Norman A. Zigrossi, President, Resource Group; Dr. Ralph H. Brooks, Vice President, Water Management and Mr. Christopher D. Ungate, Manager, Clean Water Initiative.

The U.S. Army Corps of Engineers Aquatic Plant Control Research Program (APCRP) is sponsored by the HQUSACE, and is assigned to the WES under the purview of the Environmental Laboratory (EL). Because of expertise developed in the APCRP, the WES was designated to conduct the applied research segment of the JAGP and to participate with TVA in certain demonstrations. Funding for the APCRP is provided under Department of the Army Appropriation 96X3122, Construction General. The APCRP is managed under the Environmental Resources Research and Assistance Programs (ERRAP), Mr. J. Lewis Decell, Manager. 
Mr. Robert C. Gunkel, Jr., is Assistant Manager, ERRAP, for the APCRP. Technical Monitor for the APCRP is Ms. Denise White, HQUSACE. Work is conducted under the general supervision of Dr. John Harrison, Director, EL; COL Leonard G. Hassell, EN, Commander, WES; and Dr. Robert W. Whalin, Director, WES.

Nashville District's involvement in the JAGP includes participation in overall plan development and serving on the project management team. As part of the comprehensive project, TVA has transferred funding to the District for preparation of a Master Plan and NEPA document for aquatic plant management on Guntersville Reservoir. This work is performed within the Environmental Resources Branch, Engineering-Planning Division, under the direction of Mr. H. Joe Cathey. Point of contact for the project is Mr. C. Tom Swor. Commander of the Nashville District is LTC Stephen M. Sheppard.

The work reported herein was conducted primarily by scientists from the EL of the USAE Waterways Experiment Station. The report was written by Dr. Craig S. Smith, Mr. William F. James, and Dr. John W. Barko of the EL. Mr. Harry Eakin and Mr. Kevin Pigott of the EL. Mr. Douglas Murphy and Mr. David Brewster of the Guntersville Reservoir Aquatic Research Facility, TVA, assisted in the field work, including construction and deployment of the platforms, maintenance of thermistor stations, and assistance with dye studies. Mr. R. Michael Stewart of the EL and Mr. Michael L. Schneider of the WES Hydraulics Laboratory reviewed the report. 
Executive Summary $\ldots \ldots \ldots \ldots \ldots \ldots \ldots \ldots \ldots \ldots \ldots$

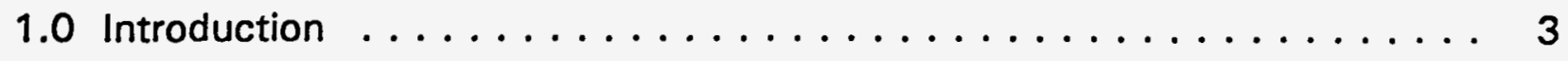

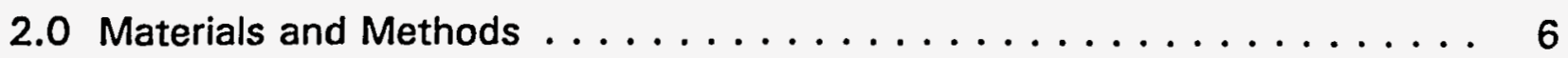

2.1 Study Site ....................... 6

2.2 Temperature and Weather Stations . . . . . . . . . 6

2.3 Analysis of Temperature Data . . . . . . . . . . . 7

2.4 Dye Injection Studies . . . . . . . . . . . . . . 8

3.0 Results . . . . . . . . . . . . . . . . . . 10

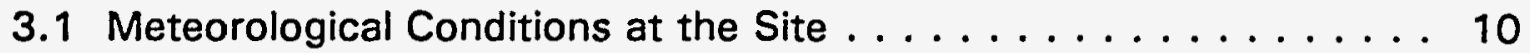

3.2 Water Temperatures .................... 11

3.3 Analysis of Water Temperature Patterns . . . . . . . . . 14

3.4 Dye Movement . . . . . . . . . . . . . . . . . . 17

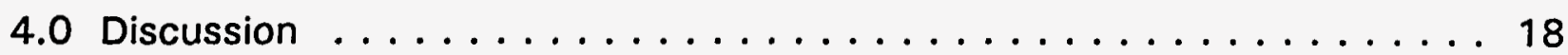

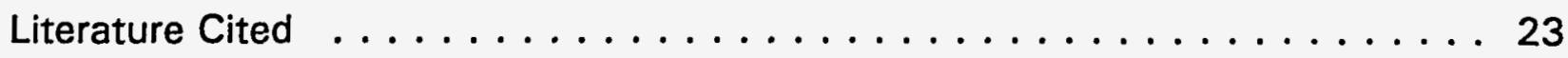

Figures $1-18$

Tables 1-2 


\section{Executive Summary}

Convective circulation patterns were examined in the Minky Creek embayment of Guntersville Reservoir, Alabama, during the period mid-August through mid-October, 1990 and mid-May through mid-November 1991. This report describes the results obtained during 1991. A transect approximately 400 $m$ in length was established on the northwestern side of the embayment and a longer transect approximately $1700 \mathrm{~m}$ in length was established down the main axis of the embayment. Three temperature recording stations were located along the short transect, four along the long transect, and one at their intersection. Water temperatures at $0.25-$ to $0.50-\mathrm{m}$ depth intervals were recorded at half-hour intervals at each station. Air temperature, relative humidity, and solar irradiance were recorded every half hour at one station. Wind speed and direction were measured every two minutes and the averages recorded every half hour at two locations, one near the mouth and the other near the head of the embayment.

On a diel basis, daytime heating produced a warm surface layer at all stations. During nighttime cooling, this layer was often eliminated. For much of the study period, vertical temperature stratification was minimal except during periods of heating or cooling. Shallow stations heated and cooled more rapidly than other stations on a diel basis, and were typically warmer during the day and cooler at night than deeper stations. The resulting horizontal temperature gradients indicate a strong potential for convective circulation. 
During differential heating, shallow regions were often heated to the bottom, while warming was confined to surface layers at deeper locations. Under these conditions warmed surface water moved outward from the shallows as an overflow and was replaced by a subsurface current of cooler water moving in the opposite direction.

During differential cooling, water moved from shallow regions as an underflow of cool water and was replaced by a return current of warmer surface water from deeper regions. This type of circulation pattern was penetrative, as water located near the surface during the daytime moved to the bottom of the embayment during nighttime cooling. Movement of injected dye during the morning and early afternoon of October 16 illustrated this circulation pattern.

Wind influenced the temperature gradients that developed during heating and cooling. The depth of the late-afternoon mixed surface layer was positively correlated with the average wind velocity during the previous 8 hours. Horizontal temperature gradients were also disrupted by wind, as shown by a negative correlation between horizontal surface temperature differences and the average wind velocity during the previous day.

These results support the contention that convective circulation can potentially be very important in reservoir embayments. These circulation patterns, occurring on a daily basis, may transfer nutrients and influence phytoplankton productivity. They also need to be considered in planning and scheduling herbicide applications. 


\subsection{Introduction}

Recent investigations have shown that convective circulation is a potentially very important mechanism for the horizontal exchange of nutrients and other substances between littoral and pelagic zones (Stefan et al. 1989; James and Barko 1991a and 1991b) and between side embayments and the main basin of reservoirs (Monismith et al. 1990). Convective circulation is driven by horizontal water temperature (and density) gradients that develop when adjacent shallow and deep regions with differing surface-to-volume ratios are heated or cooled (Figure 1). During daytime heating, water in shallow regions heats more rapidly than in deeper regions (i.e., differential heating), resulting in horizontal movement of shallow water as a surface flow over cooler water in the deep region (Monismith et al. 1990). During nighttime cooling, the opposite pattern occurs. Water in shallow regions cools more rapidly than in deeper regions (i.e., differential cooling), resulting in horizontal movement of shallow water as an underflow below warmer water in the deep region, until a similar density stratum is encountered in the water column (Monismith et al. 1990). These circulation patterns, occurring on a daily basis, can have a pronounced effect on nutrient dynamics and phytoplankton productivity. They also have implications for aquatic macrophyte management, since water movement can influence both herbicide contact times and the spatial distribution of effective control. 
CONVECTIVELY-DRIVEN CIRCULATION

CAUSED BY DIFFERENTIAL HEATING AND COOLING OF SHALLOW AREAS

\section{HEATING}
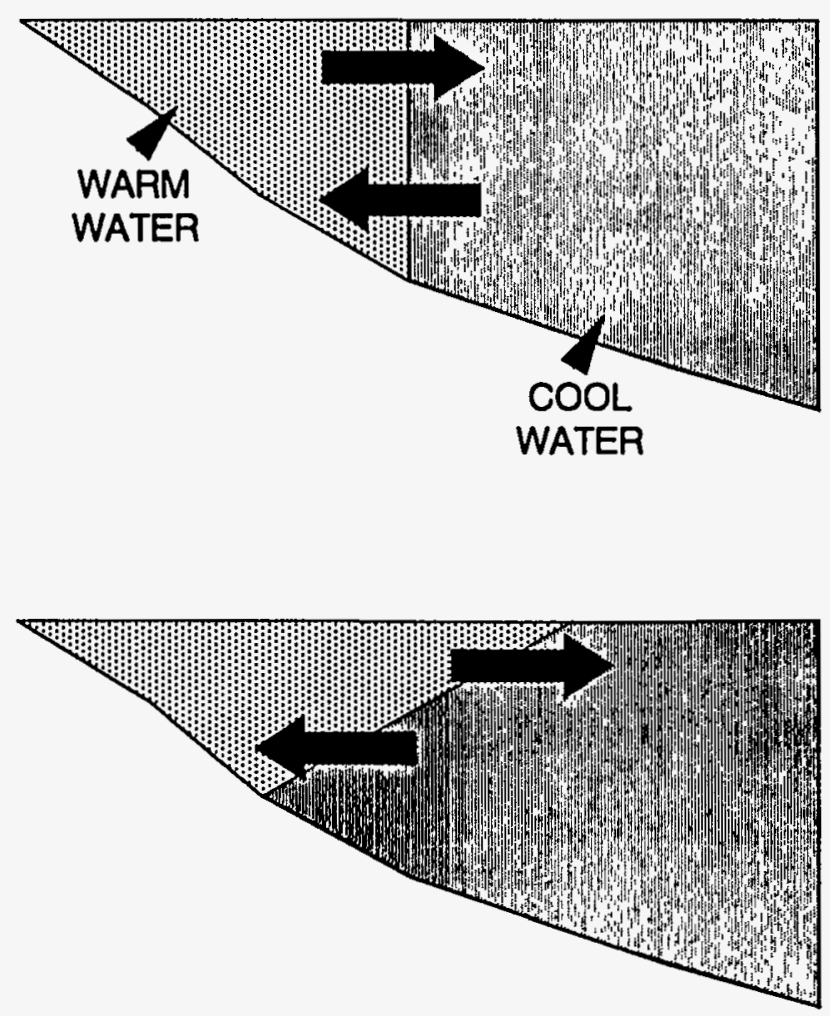

\section{COOLING}
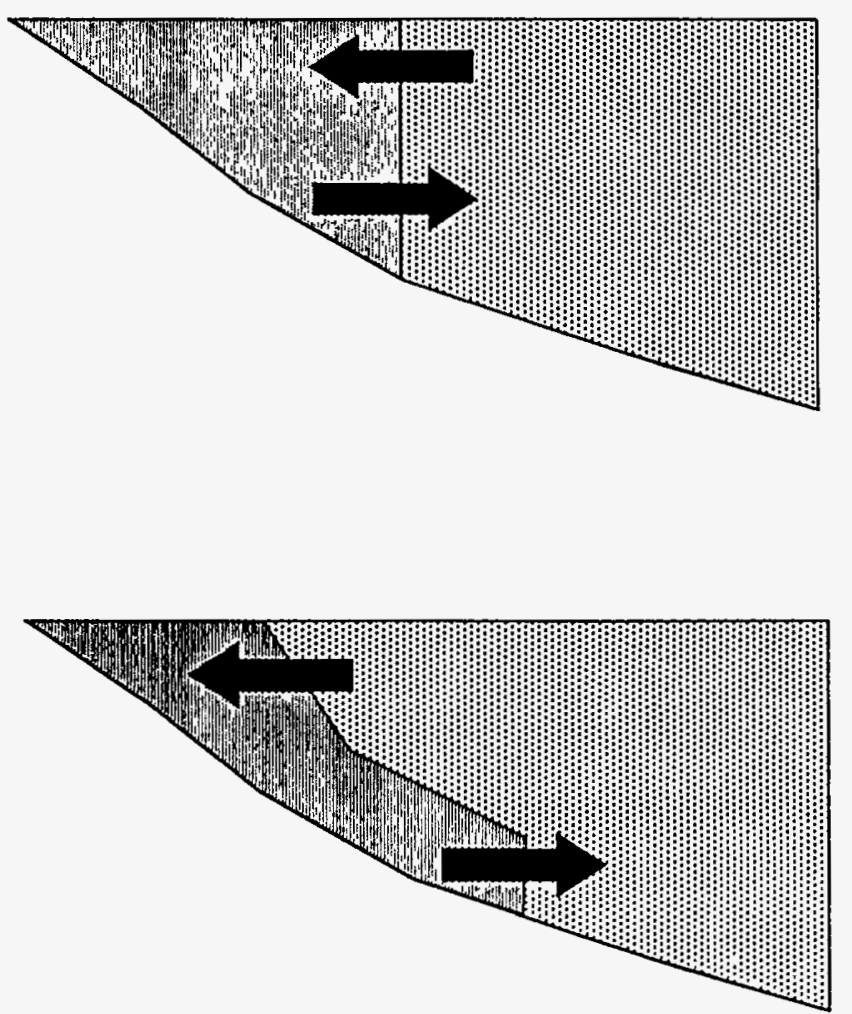

Figure 1. Induction of convective water movements in shallow embayments by differential heating and cooling of the shallows. 
As the size of water bodies increases and sheltering decreases, the importance of wind-driven circulation increases. In shallow embayments of larger water bodies, patterns of circulation are driven by both convection and wind stress. Several types of wind effects are likely. Wind velocity drives vertical mixing and therefore determines the depth of the surface mixed layer. On calm days surface waters can become intensely stratified, while they may become almost completely destratified on windy days. Wind-driven currents redistribute heated surface water, affecting the development of the horizontal temperature gradients that drive convection (James and Barko 1991b).

Wind direction would be expected to determine the nature of the interaction between wind- and convection-driven currents. Winds driving water in the same direction as convection can be expected to produce substantially greater water movements than due to convective transport alone. Winds opposing convective circulation may facilitate the development of substantial thermal gradients while retarding convective circulation. Winds moving water laterally across thermal gradients can potentially produce complex circulation patterns.

As part of the Joint Agency Guntersville Project, sponsored by the Tennessee Valley Authority (TVA) and the Headquarters, US Army Engineers (HOUSACE), we examined differential heating, cooling, and resultant convective circulation patterns in an embayment (Minky Creek) of Guntersville Reservoir, 
Alabama during 1990 and 1991. We used vertical and horizontal variations in water temperature to examine differential heating and cooling in the reservoir. Our objectives were to identify temperature patterns likely to produce convective circulation in this embayment and to document the frequency of their occurrence.

Preliminary results from 1990 were summarized previously (James 1991). This report summarizes results of more extensive studies conducted in 1991. 


\subsection{Materials and Methods}

\subsection{Study Site}

Guntersville Reservoir, located on the Tennessee River in northeastern Alabama, is a hydropower and flood control impoundment operated by the Tennessee Valley Authority. The Minky Creek embayment of the reservoir (Figure 2) is relatively shallow (maximum depth of approx. $6 \mathrm{~m}$ ), with an extensive littoral zone. Prior to 1990, the shallows were dominated by the submersed macrophyte, Myriophyllum spicatum. Macrophyte biomass declined during 1990 in the Minky Creek embayment, as well as in other regions of the reservoir, and the embayment was essentially devoid of submersed vegetation throughout this study.

\subsection{Temperature and Weather Stations}

In 1991 water temperatures were measured along two transects (Figure 3). A lateral transect extended approximately $400 \mathrm{~m}$ out from the northern shore of the embayment. Stations for water temperature monitoring were located at the 1.0- (50 $\mathrm{m}$ from shore), 2.0- (125 $\mathrm{m}$ from shore), 3.5- (175 $\mathrm{m}$ from shore), 5.0( $275 \mathrm{~m}$ from shore), and $5.75-\mathrm{m}$ ( $375 \mathrm{~m}$ from shore) depths on this transect. A second transect extended along the central axis of the embayment to the outermost station on the lateral transect, $1900 \mathrm{~m}$ from the head of the bay. Four additional temperature stations were arrayed along the central axis at depths of 


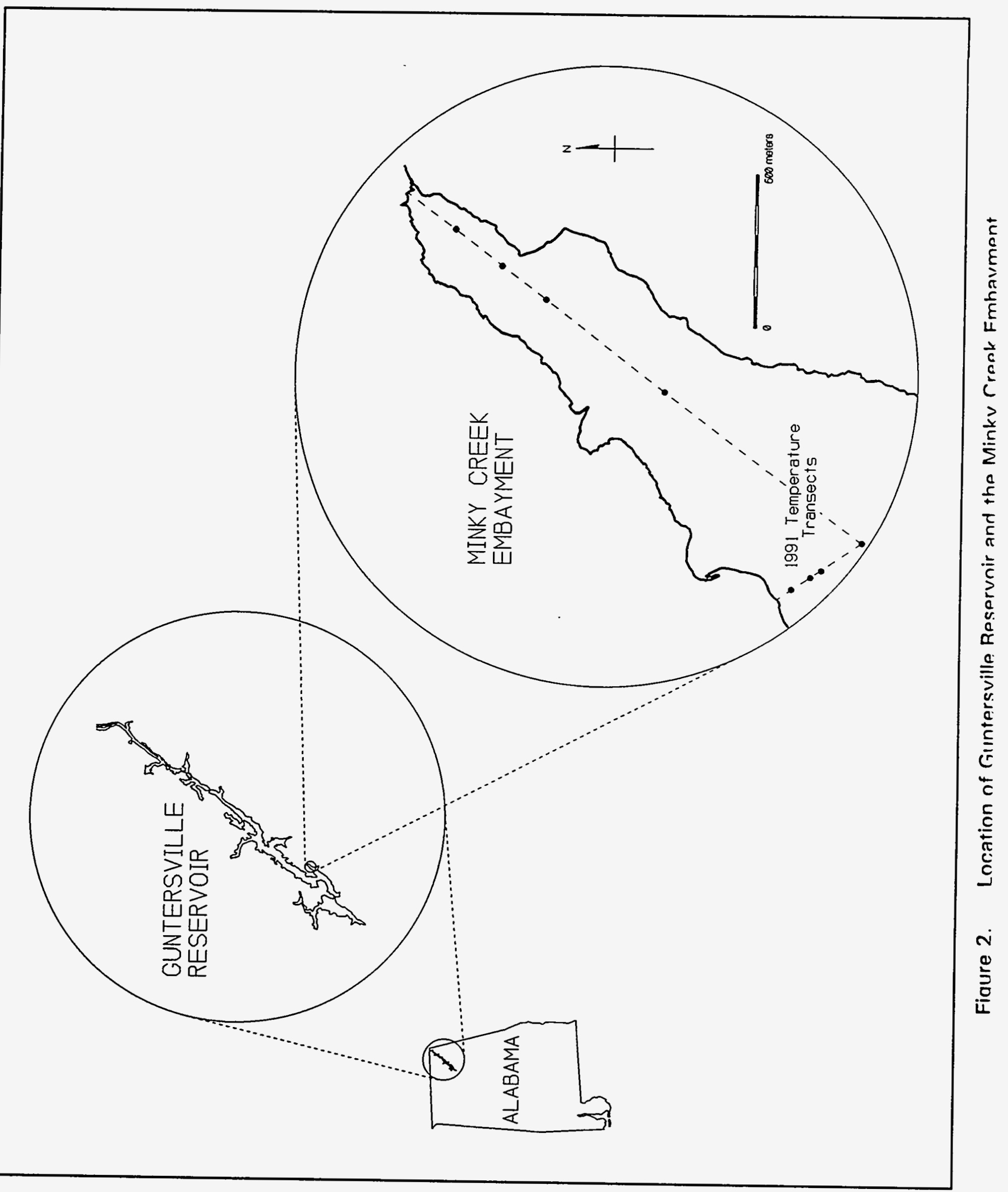


Minky Creek Embayment

Guntersville Reservoir

1991 Temperature Station Locations

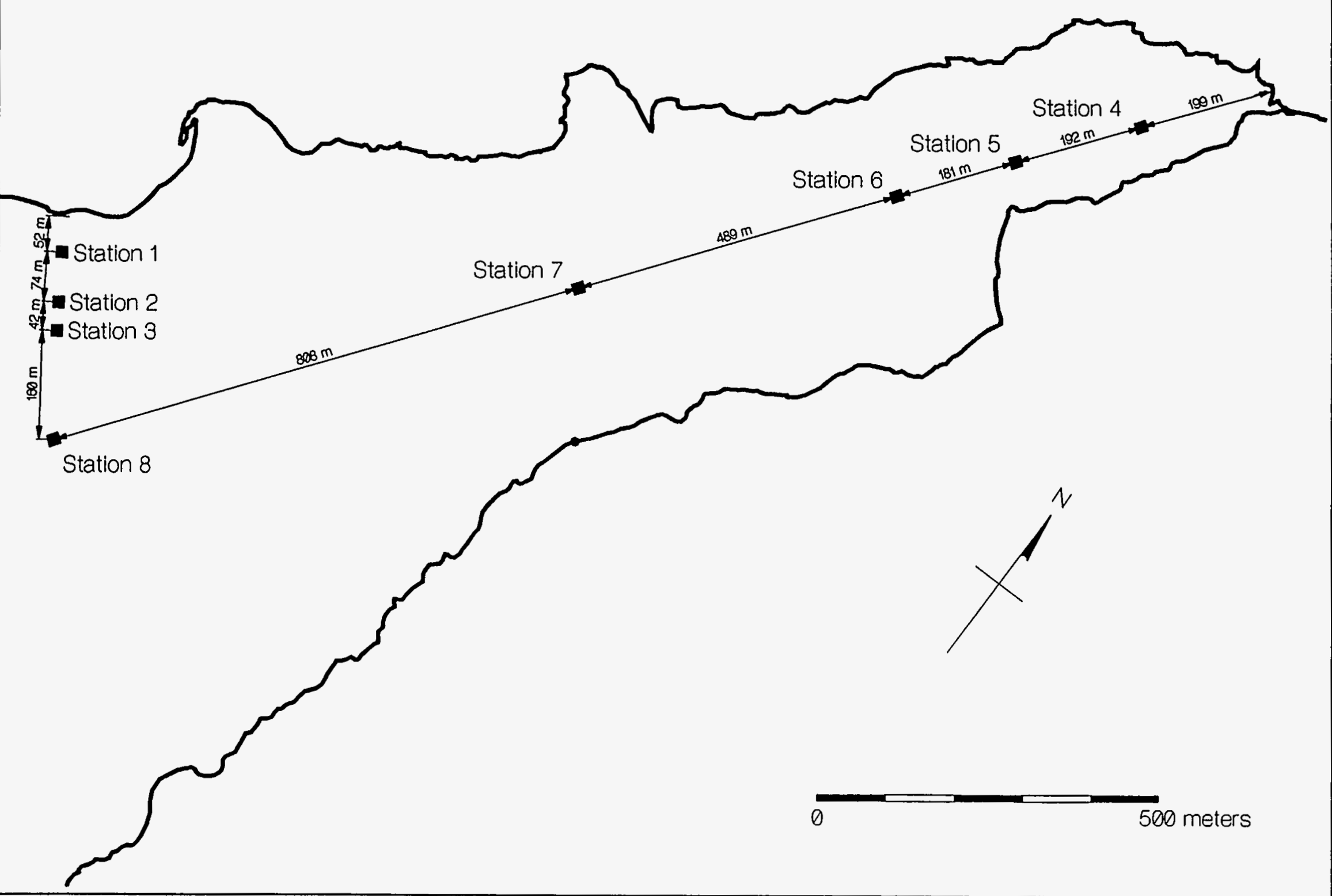

Figure 3. Locations of temperature monitorina stations durinn 1991. 
$0.8,1.5,2.2$, and $3.8 \mathrm{~m}$, corresponding to distances of approximately 200,400 , 600 , and $1100 \mathrm{~m}$ from shore, respectively. Recording temperature monitors (Omnidata International) were placed on permanently-positioned platforms at all stations. Instantaneous water temperatures were measured every half hour at all stations with thermistor probes precalibrated to the nearest $0.01^{\circ} \mathrm{C}$. Thermistor probes were positioned at $0.25 \mathrm{~m}$ depth increments from $0.25 \mathrm{~m}$ to the bottom in locations less than $3.0 \mathrm{~m}$ deep. In deeper locations, thermistors were located at a depth of $0.25 \mathrm{~m}$, and at $0.50 \mathrm{~m}$ depth increments from $0.5 \mathrm{~m}$ to the bottom. Half-hour averages of wind speed and direction measurements made every 2 minutes were recorded at the outermost station (Station 8 ) and the one nearest the head of the embayment (Station 4). Instantaneous measurements of air temperature, relative humidity and solar irradiance were recorded every 30 minutes at Station 6. Water temperature and meteorological data were not obtained during several periods, due to equipment malfunctions (Table 1 ).

\subsection{Analysis of Temperature Data}

This report focuses primarily on the development of temperature patterns along the central axis of the embayment (Stations 4 through 8 ). Isotherms were drawn from water temperature observations by kriging, using the commercial software package, Surfer. In determinations of vertical stratification, the daily mixed layer was considered to extend from the surface to the first thermal stratum having a temperature gradient of $1^{\circ} \mathrm{C} / \mathrm{m}$ or greater. The depth of the mixed layer 
TABLE 1. Gaps in the 1991 temperature and weather database.

\begin{tabular}{|c|c|c||}
\hline \multirow{2}{*}{ Station } & \multicolumn{2}{|c|}{ Periods of Missing Data' } \\
\cline { 2 - 4 } & From & To \\
\hline \hline 1 & $09 / 2711: 30$ & $\begin{array}{c}\text { END OF 1991 } \\
\text { STUDY }\end{array}$ \\
\hline 2 & $09 / 3013: 00$ & $10 / 0115: 00$ \\
\hline 3 & $06 / 1312: 00$ & $06 / 1812: 00$ \\
& $08 / 0510: 30$ & $08 / 1300: 00$ \\
& $08 / 2302: 30$ & $08 / 2614: 30$ \\
& $09 / 1615: 00$ & $09 / 1809: 30$ \\
& $09 / 3013: 00$ & $10 / 0209: 30$ \\
& $10 / 2521: 30$ & $10 / 3010: 30$ \\
\hline $4^{3}$ & $08 / 0511: 00$ & $08 / 0717: 00$ \\
\hline 5 & $09 / 1509: 30$ & $09 / 1809: 00$ \\
\hline $6^{3}$ & $06 / 1716: 00$ & $06 / 2815: 30$ \\
& $07 / 2314: 00$ & $08 / 0210: 00$ \\
& $08 / 0512: 00$ & $08 / 0717: 00$ \\
& $08 / 1019: 30$ & $08 / 1712: 00$ \\
& $08 / 2716: 30$ & $08 / 2813: 00$ \\
\hline 7 & $11 / 0412: 30$ & $11 / 0415: 30$ \\
\hline $8^{3}$ & $06 / 1313: 00$ & $06 / 2112: 00$ \\
& $06 / 2815: 30$ & $07 / 1817: 00$ \\
& $10 / 0711: 00$ & $10 / 1112: 00$ \\
& $10 / 2510: 30$ & $10 / 2815: 00$ \\
\hline
\end{tabular}

${ }^{1}$ Defined as periods longer than 2 hours during which an entire temperature-recording station was not functioning.

${ }^{2}$ Station was moved to a new location.

${ }^{3}$ Includes meteorological data. 
each day was determined at 1600 hours, when daytime thermal stratification is typically maximal. Near-surface horizontal temperature gradients along the central axis of the embayment were calculated as the difference between temperatures measured at the $0.25 \mathrm{~m}$ depth at Stations 8 and 5 . The innermost station (4) was not used for comparisons because of malfunctions in the $0.25 \mathrm{~m}$ temperature sensor.

Patterns of thermal stratification along the main axis of the embayment during 1991 were compared using cluster analysis. Water temperature observations at each time interval were first normalized by expressing each as a difference from the deepest measurement at the station furthest offshore (i.e., 5.0 $m$ depth at Station 8 ). Normalization highlighted relative differences between locations, and eliminated overall seasonal temperature trends. Normalized water temperature observations were then analyzed using the procedure FastClus in SAS (SAS Institute Inc. 1988). The maximum number of clusters was arbitrarily set at 6. FastClus ignores observations with missing values in constructing clusters, but assigns such observations to clusters, where possible.

\subsection{Dye Injection Studies}

On 16 October 1991, water movements were traced by injecting dye and following its movement. Prior to the injection of dye, 34 marker buoys were placed along the main axis of the embayment at $25 \mathrm{~m}$ intervals from Station 4 to Station 7. The study commenced with the injection of dye at 0800. A mixture of 
4.2 L Rhodamine WT and 4.2 L of methanol was diluted with approximately $7 \mathrm{~L}$ of lakewater for injection. The injection area was $20 \mathrm{~m} \times 4 \mathrm{~m} \times 1 \mathrm{~m}$ deep and was located $30 \mathrm{~m}$ from Station 5 between Stations 5 and 6 . Dye was injected at 0.0 , 0.5 , and $1.0 \mathrm{~m}$ depths in order to distribute dye vertically throughout the water column. The dye mixture was injected by pumping it through an herbicide-injection manifold about $2 \mathrm{~m}$ in length at a rate of $0.07 \mathrm{~L} / \mathrm{s}$ while the boat moved back and forth through the injection zone ( 2 injections sweeps at each depth). The injection took approximately 20 minutes to complete.

Dye movement was tracked by measuring dye concentrations with a fluorometer. Concentration measurements were made at $0.25 \mathrm{~m}$ depth intervals at marker buoy locations along the central transect and at other arbitrary locations to either side of the transect. Positions of sampling stations off the central transect were approximated by estimating the distance and direction to the nearest marker buoys. The distribution of dye at the surface was also estimated visually and traced onto a map of the embayment. Sampling began within 1 hour of injection and continued until 1530. 


\subsection{Results}

\subsection{Meteorological Conditions at the Site}

Excluding diel variation, air and water surface temperatures were relatively stable from early June until mid-September of 1991 (Figure 4). A general downward trend in air and water temperatures began in mid September and continued until the end of the study in mid-November. Short-term warming and cooling trends, each lasting a few days, were frequent throughout both the stable and declining periods.

Daily average wind velocities and directions at the outermost station (Station 8) during May through November 1991 are shown in Figure 5. Daily average wind velocities during this period ranged from 0.8 to $4.7 \mathrm{~m} / \mathrm{sec}$. Average wind direction was highly variable. Winds rarely originated in the quadrant from northwest to northeast, those that did were never strong. During the spring and summer, winds were frequently from the southeast. Winds from the NW to WNW were uncommon during the summer, but increased in September and October, and became predominant in November.

\subsection{Water Temperatures}

Examples of the temperature changes produced by differential heating and cooling are shown in Figures 6 through 12. Each of these figures illustrates 


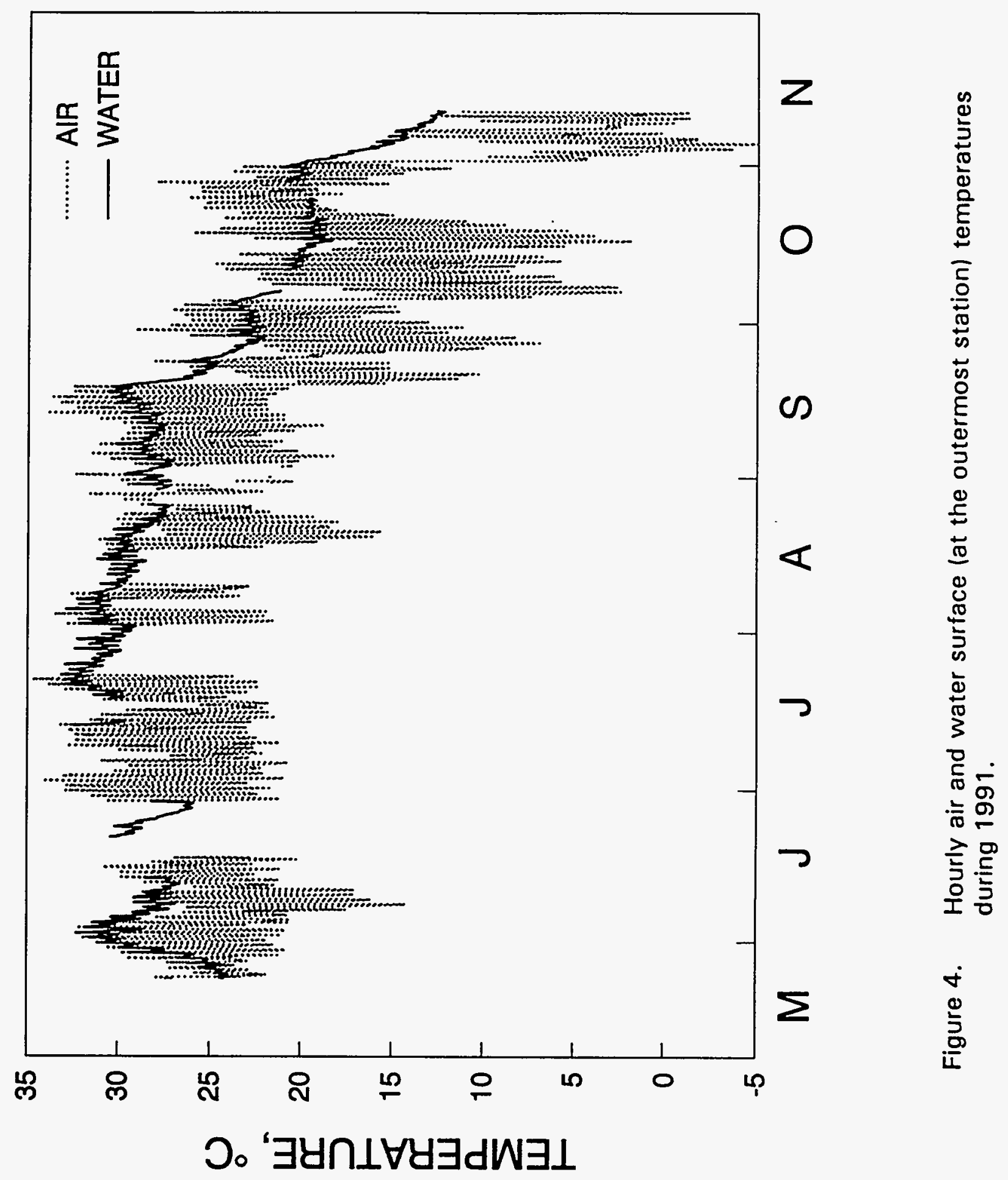


rigure 5. Listridution or dally average wind direction and velocity, 7991. Arrows point in the direction of air movement (i.e. away from the source of the wind) and arrow length is proportional to daily average wind velocity.

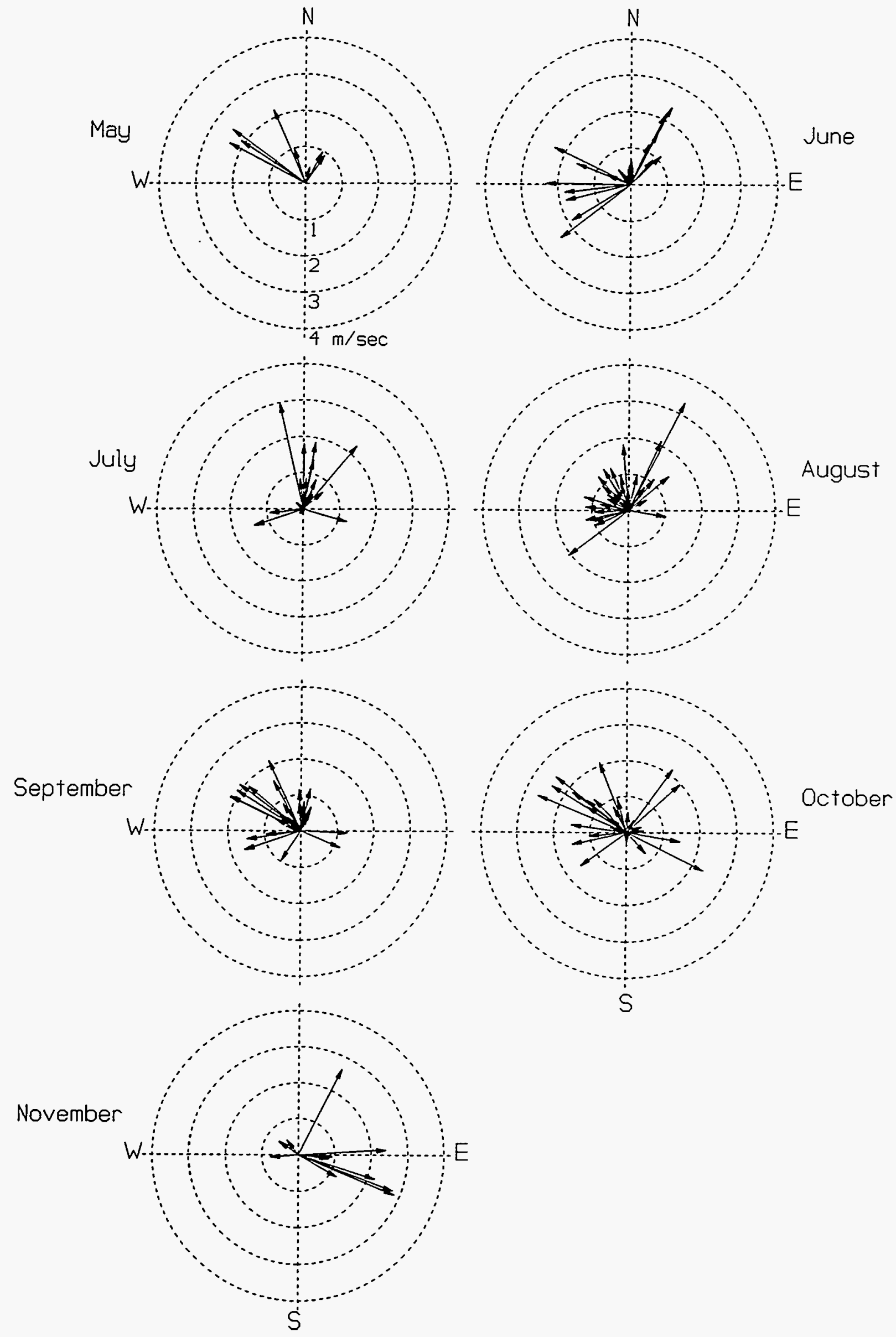


isotherms drawn every four hours for a randomly-selected 24 hour period, one from each month during which temperature measurements were taken during 1991.

From May 29-30 there was considerable differential heating of the shallows during the daytime and only very limited nighttime cooling (Figure 6). These dates fell in the middle of an overall warming period, which lasted several days. Surface water temperatures along the central axis of the embayment increased by 1 to 2 ${ }^{\circ} \mathrm{C}$ from the beginning of the period until the end. While the water throughout most of the embayment was still warming up, there was very strong vertical stratification at the deeper stations ( $>2.0 \mathrm{~m}$ deep). The two shallowest stations $(<1.5 \mathrm{~m}$ deep) were unstratified in the morning (0800 hours) and stratified only briefly (1200 hours) before daytime heating warmed the entire shallows (1600 and 2000 hours).

June 7-8 occurred during a cooling period, as there was considerable nighttime cooling but little differential heating (Figure 7). For the morning of June 7, isotherms show the characteristic pattern which indicates nighttime convective circulation, i.e., a mass of cool water moving downslope from the shallows.

Daytime heating on June 7 resulted in the warming of only a shallow layer, and was just sufficient to produce uniform surface temperatures along the transect by 1600. By late afternoon (1600) all traces of a horizontal temperature gradient disappeared. Nighttime cooling was substantial and left surface temperatures 1 to $2{ }^{\circ} \mathrm{C}$ cooler at the end of this period than at the beginning. By $0800 \mathrm{cool}$ water 
Figure 6. Temperature patterns along the central transect at four-hour intervals on May 29 and 30, 1991. Asterisks show the locations of temperature sensors.
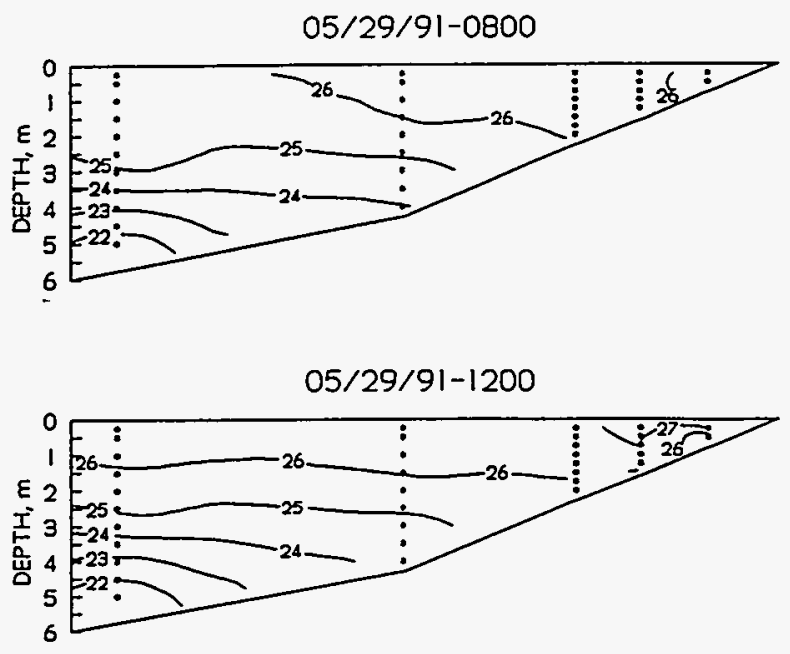

05/29/91-1600
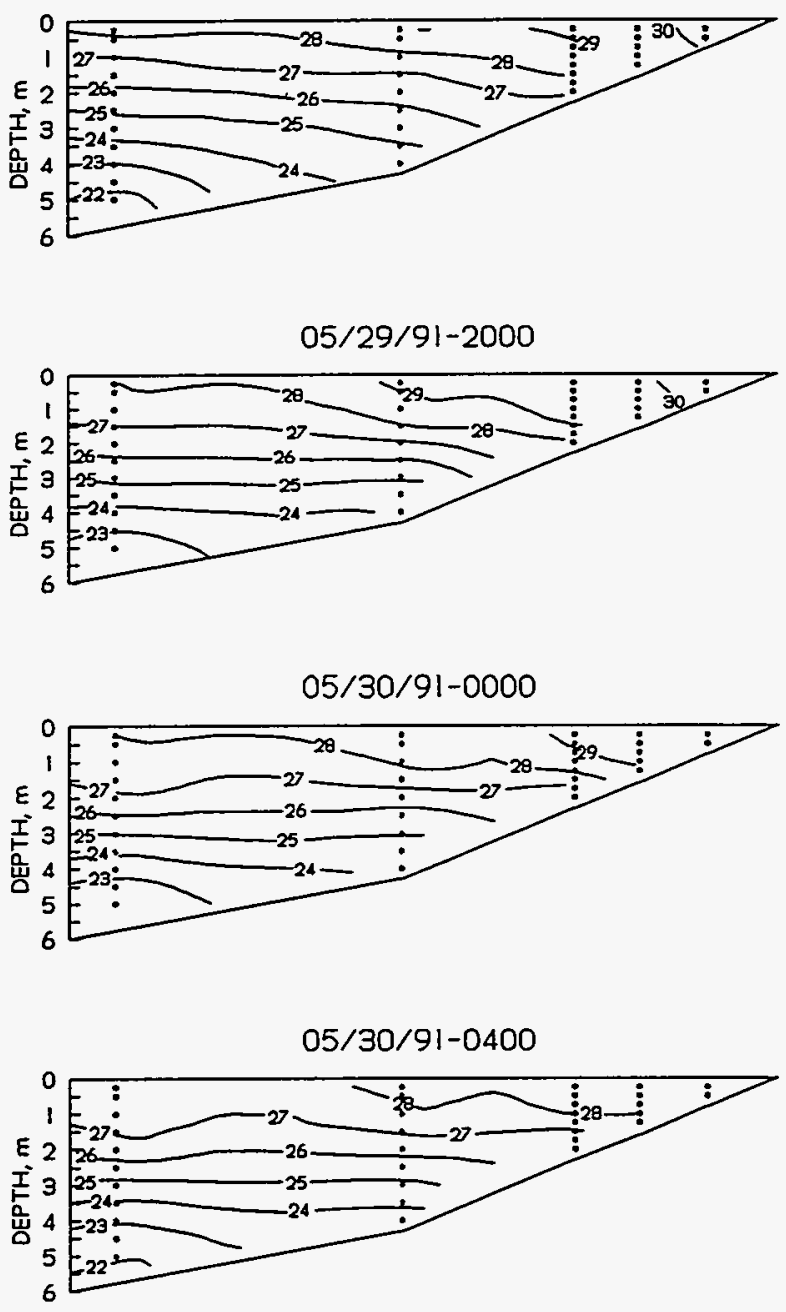

05/30/91-0800

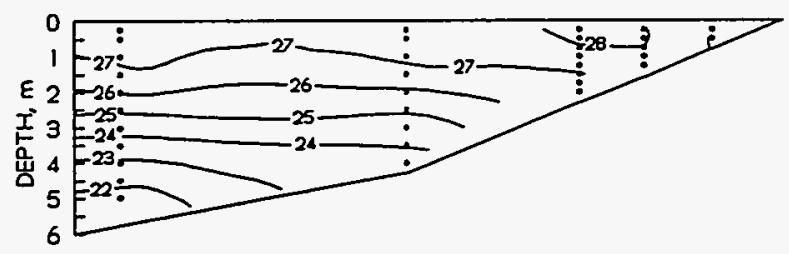


Figure 7. Temperature patterns along the central transect at four-hour intervals on June 7 and 8, 1991. Asterisks show the locations of temperature sensors.

\section{6/07/91-0800}

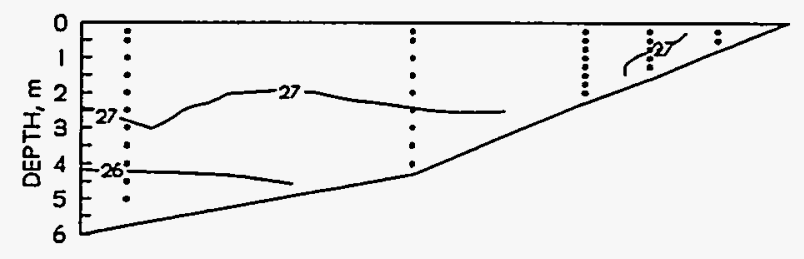

$06 / 07 / 91-1200$
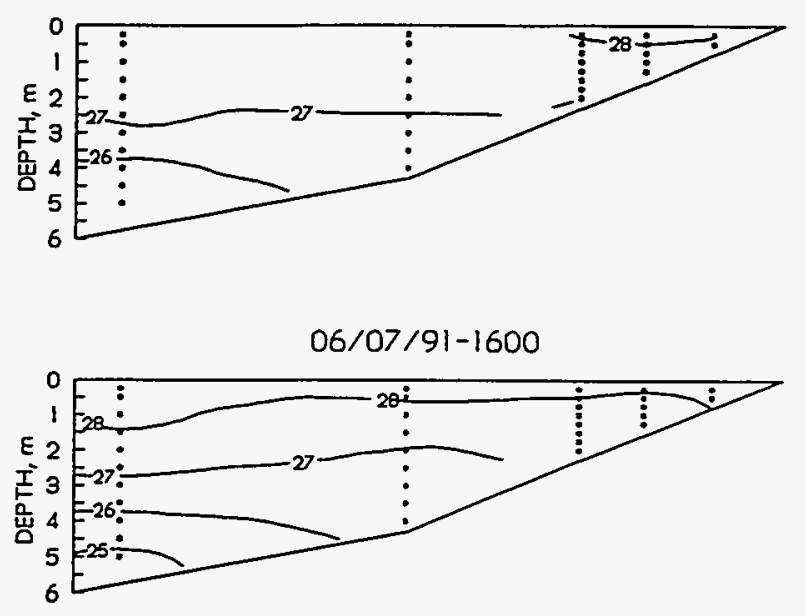

06/07/91-2000

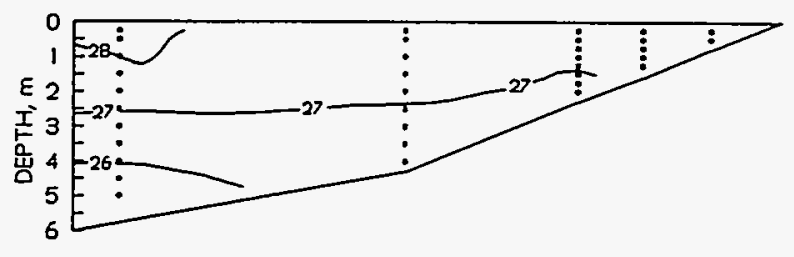

06/08/91-0000
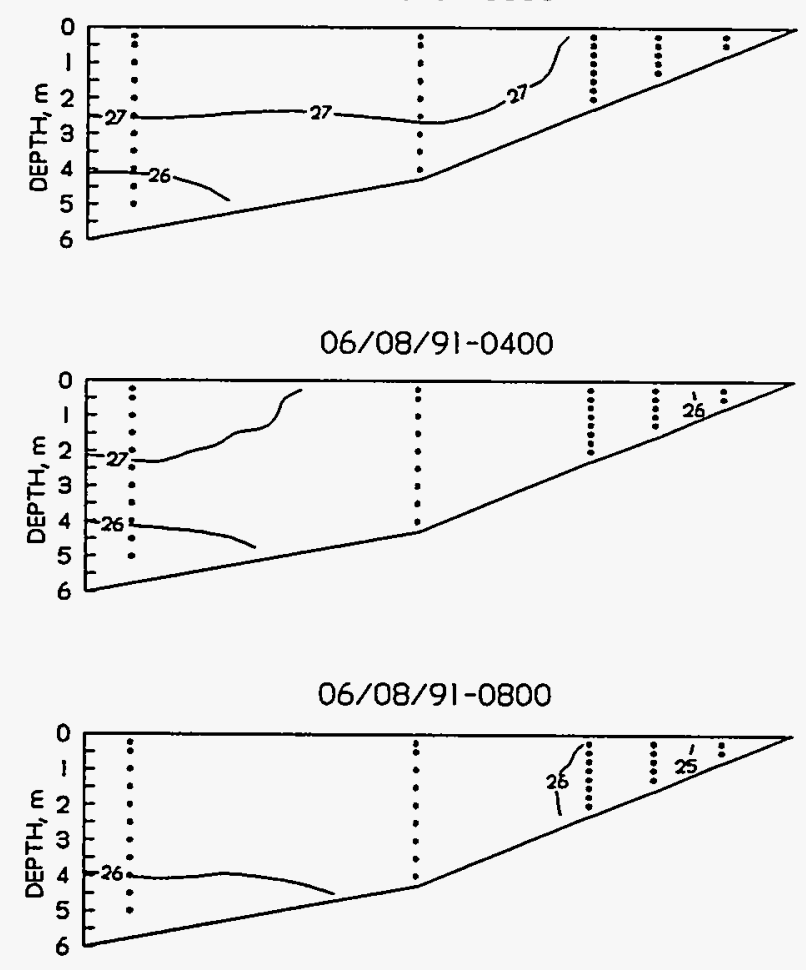
extended out past Station 6, but there was little evidence of an underflow of cold water, probably owing to vertical mixing caused by relatively strong winds lup to $14 \mathrm{~m} / \mathrm{sec}$ ) during the night.

Isotherms from July 28-29 illustrate temperature changes common during much of the summer (Figure 8). By this time of year the entire embayment had warmed, and vertical stratification was short-lived and confined to periods following heating or cooling. As on many dates, heating and cooling were substantial but comparable, and water temperatures at the end of the period were very similar to initial ones. At 0800 on July 28 , temperatures in most of the embayment were between 29 and $30^{\circ} \mathrm{C}$. The shallowest station had cooled overnight and was slightly below $29^{\circ} \mathrm{C}$. By 1600 , daytime heating had produced strong vertical stratification in the upper $2.0 \mathrm{~m}$ of the water column. Surface temperatures at the two shallowest stations exceeded those elsewhere by up to $1^{\circ} \mathrm{C}$, but differential warming of the shallow was largely confined to the surface. Strong stratification persisted until 2000, but dissipated overnight. By 0800 on July 29 , the embayment was again nearly isothermal.

August 19-20 was another period during which strong heating and cooling were nearly balanced, producing little net temperature change (Figure 9). At 0800 on August 19 the area around the shallowest station and the bottom layers (below $3.0 \mathrm{~m}$ ) at the outermost two stations were slightly below $29^{\circ} \mathrm{C}$, while other areas were slight above $29^{\circ} \mathrm{C}$. Daytime heating was strongly differential, with warm temperatures extending much deeper at shallow stations than at deep ones. By 
Figure 8. Temperature patterns along the central transect at four-hour intervals on July 28 and 29, 1991. Asterisks show the locations of temperature sensors.
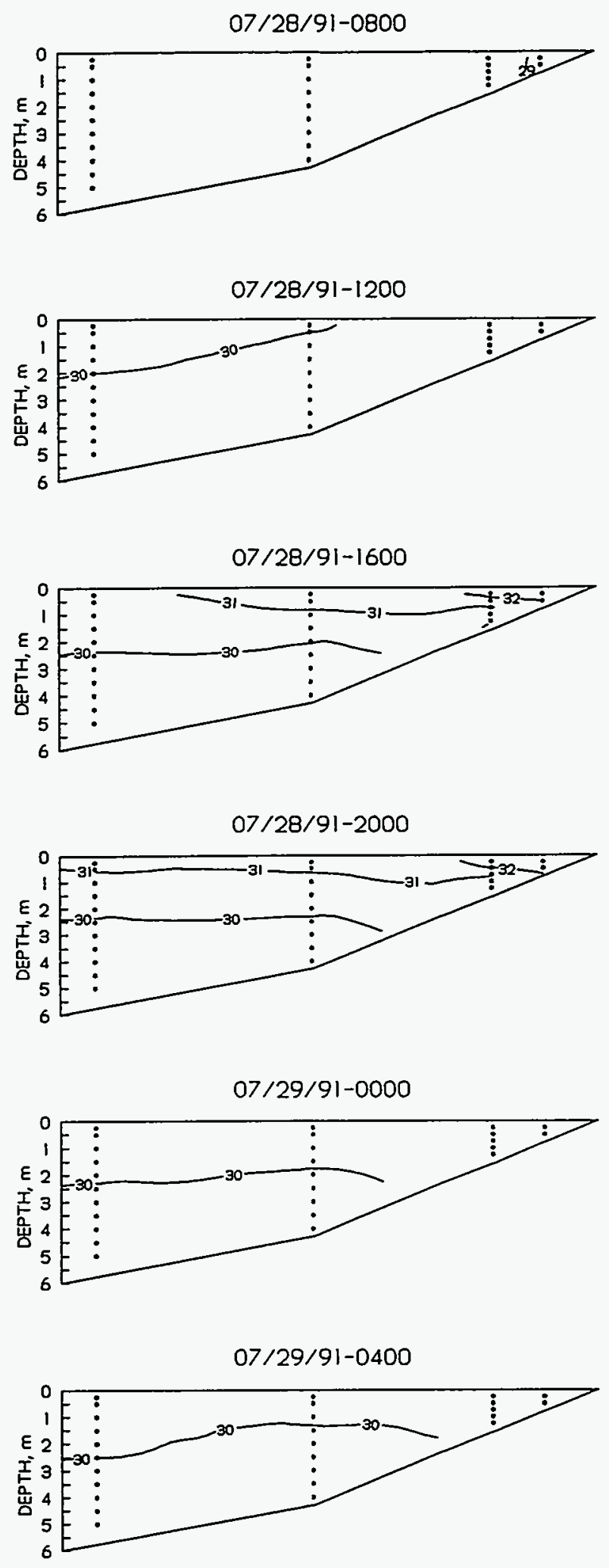

$07 / 29 / 91-0800$

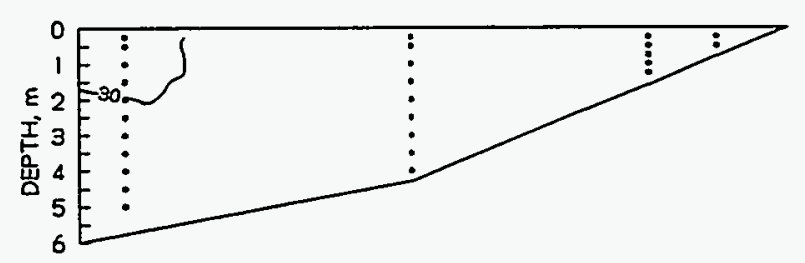


Figure 9. Temperature patterns along the central transect at four-hour intervals on August 19 and 20,1991. Asterisks show the locations of temperature sensors.
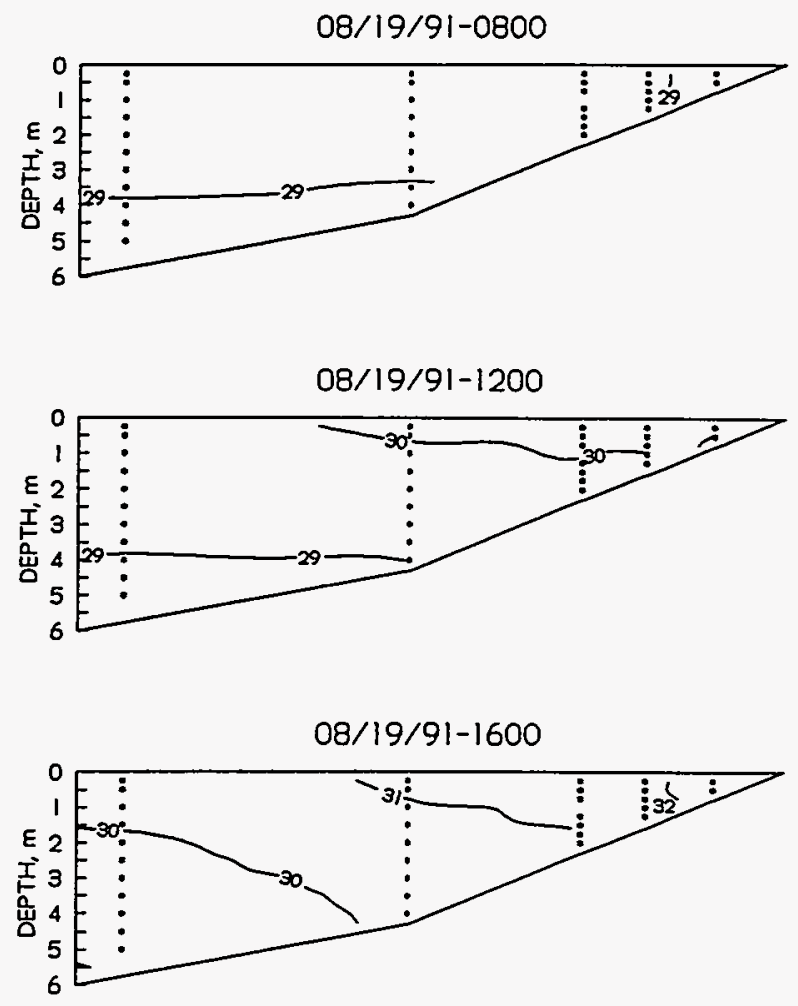

$08 / 19 / 91-2000$

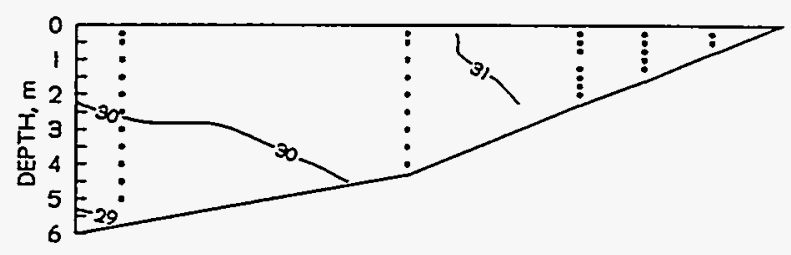

$08 / 20 / 91-0000$
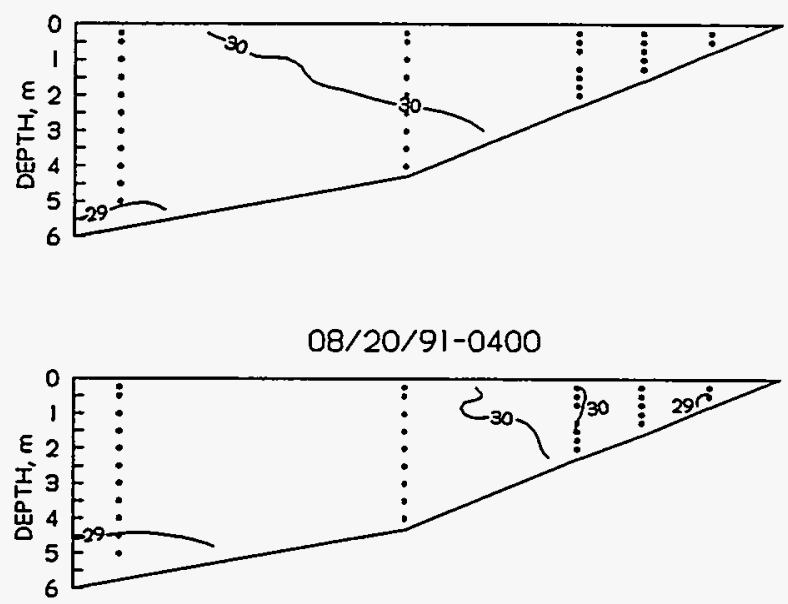

$08 / 20 / 91-0800$

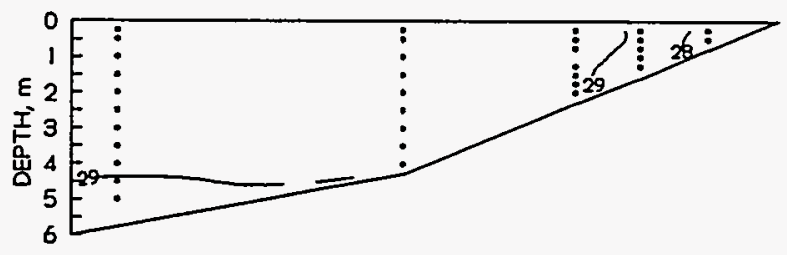


1600 , the shallowest station had been heated to temperatures above $32^{\circ} \mathrm{C}$ to the bottom and temperatures at the second and third stations (5 and 6) exceeded $31^{\circ} \mathrm{C}$ to a depth of approximately $1.5 \mathrm{~m}$. By 0400 , nighttime cooling had dropped temperatures in the shallows blow those in the center of the transect. By 0800 on August 20, the slant of isotherms between Stations 5 and 6 suggests an underflow of cooler water from the shallows. Final temperatures at the two shallowest stations were nearly $1^{\circ} \mathrm{C}$ lower than at the beginning of the time period, but temperatures elsewhere changed little during the period.

During September 13-14 heating slightly exceeded cooling (Figure 10). At the start of the period the embayment was nearly isothermal throughout. Strong daytime heating raised surface temperatures from below 28 to near $30^{\circ} \mathrm{C}$ or slightly higher by 1600 . Surface temperatures at the shallowest stations were up to $1^{\circ} \mathrm{C}$ warmer than that at the deepest station. Only the shallowest station was heated to a greater depth than other stations. By 0800 on September 14 , cooling had destratified the three shallowest stations, but the two deepest stations remained moderately stratified. Final temperatures were $0.5-1.0^{\circ} \mathrm{C}$ warmer than initial ones, with the greatest changes occurring at the deeper stations.

October 14-15 illustrates warming following a period of very strong cooling (Figure 11). At 0800 on October 14 the shallowest station was nearly $3^{\circ} \mathrm{C}$ cooler than the deepest station. Vertical stratification was absent from the ends of the transect but existed between Station 5 and 7, where isotherms suggest an underflow of cool water. Daytime heating led to development of vertical 
Figure 10. Temperature patterns along the central transect at four-hour intervals on September 13 and 14, 1991. Asterisks show the locations of temperature sensors.
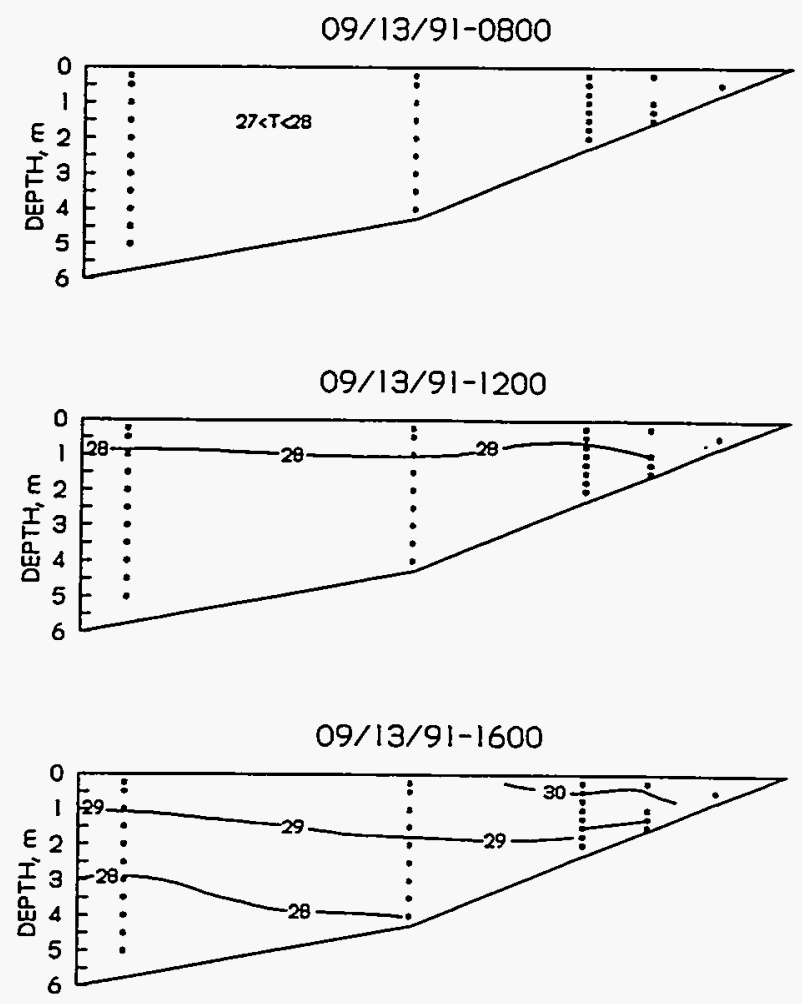

$09 / 13 / 91-2000$

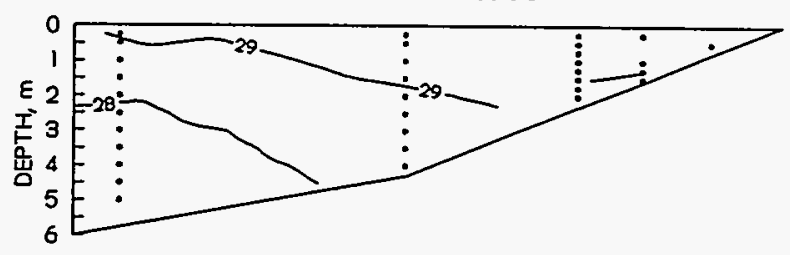

$09 / 14 / 91-0000$
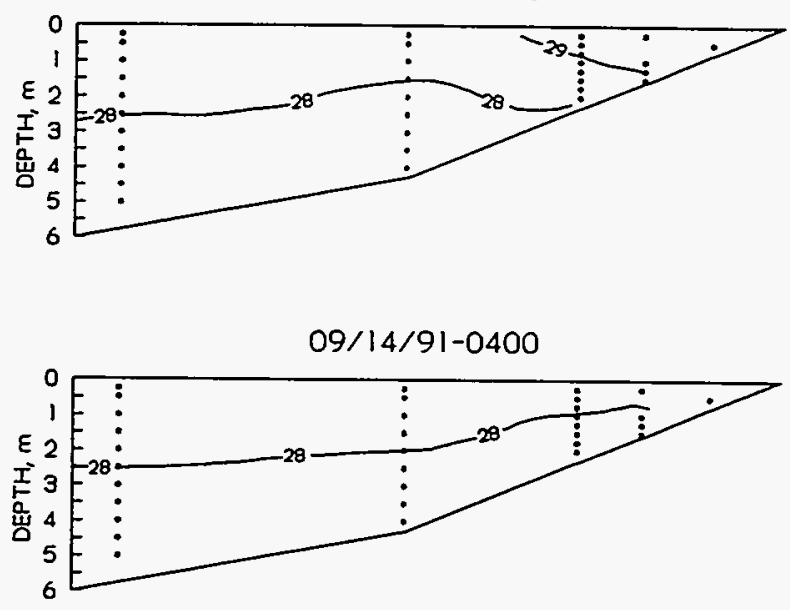

$09 / 14 / 91-0800$

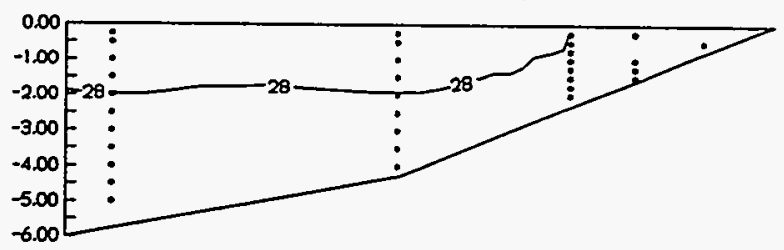


Figure 11. Temperature patterns along the central transect at four-hour intervals on October 14 and 15, 1991. Asterisks show the locations of temperature sensors.

$10 / 14 / 91-0800$
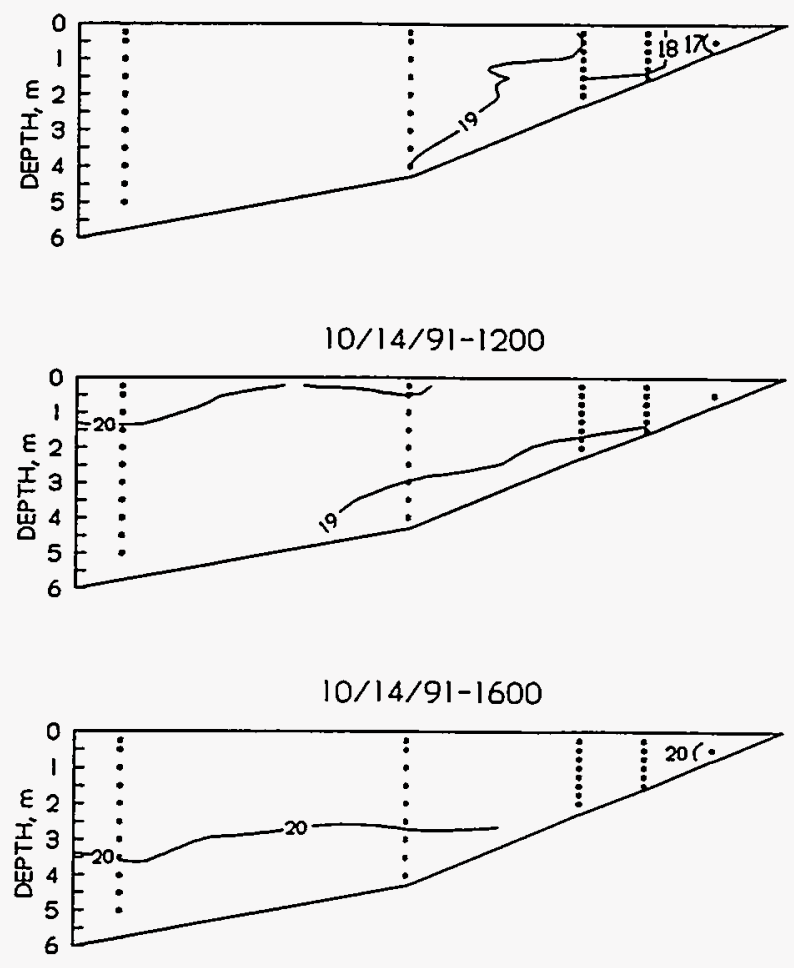

$10 / 14 / 91-2000$

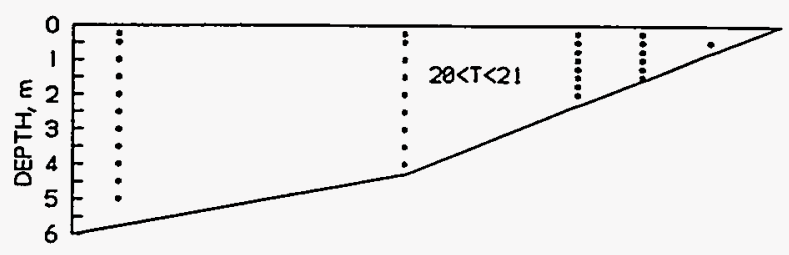

$10 / 15 / 91-0000$

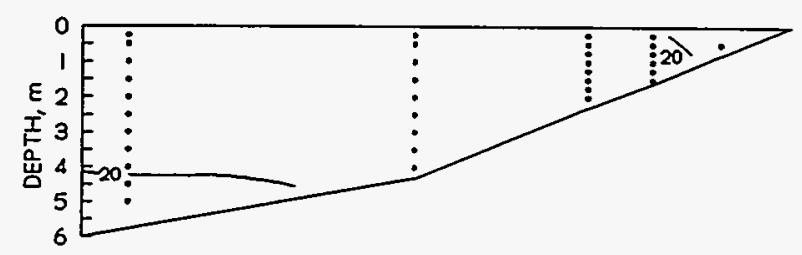

$10 / 15 / 91-0400$

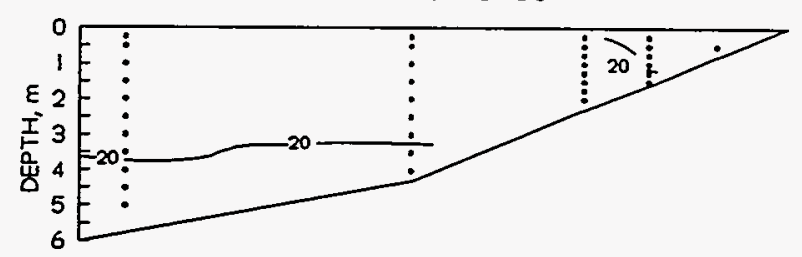

$10 / 15 / 91-0800$

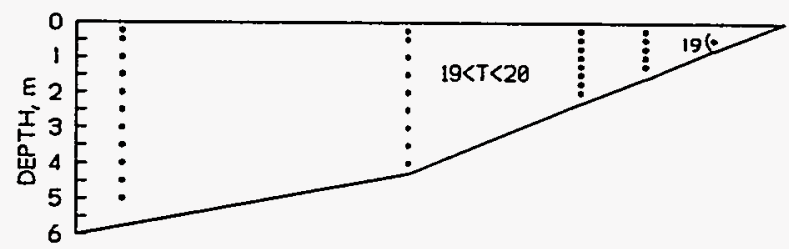


stratification at all but the shallowest stations by 1200 and horizontal temperature gradients were nearly absent by 1600 . Cooling left the embayment nearly isothermal by 2000 . Most of the embayment remained isothermal through the end of the period, with slightly cooler water only at the two shallowest stations. Final temperatures were essentially unchanged at the deepest station, but were up to $2^{\circ} \mathrm{C}$ warmer than initial temperatures at shallow stations.

November 1-2 was a period of very strong cooling (Figure 12). Final temperatures were $2-3^{\circ} \mathrm{C}$ cooler than initial temperatures over the entire embayment. At 0800 on November 1 the embayment was nearly isothermal. Weak horizontal gradients are present, with the warmest water in the central part of the transect. The warm central area dissipates during the day, and there is no evidence of daytime heating. The shallows cool dramatically during the night, and by 0800 on November 2 temperatures there are more than $3^{\circ} \mathrm{C}$ cooler than at the beginning of the period. Very cool water at station 4 and on the bottom of stations 5 and 6 suggests a considerable transport of cooler water along the bottom.

\subsection{Analysis of Water Temperature Patterns}

Cluster analysis delineated six archetypical water temperature patterns, representing differing degrees of stratification resulting from varying histories of

heating or cooling (Figure 13). Pattern 1 suggests strong differential cooling, as shown by the negative horizontal temperature gradient (i.e. cooler at shallow 
Figure 12. Temperature patterns along the central transect at four-hour intervals on November 1 and 2,1991. Asterisks show the locations of temperature sensors.

$11 / 01 / 91-0800$
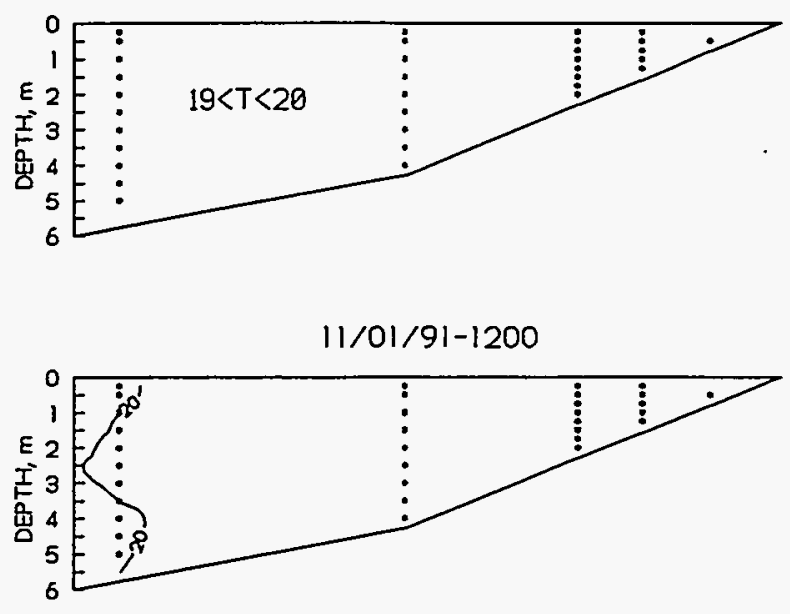

$11 / 01 / 91-1600$

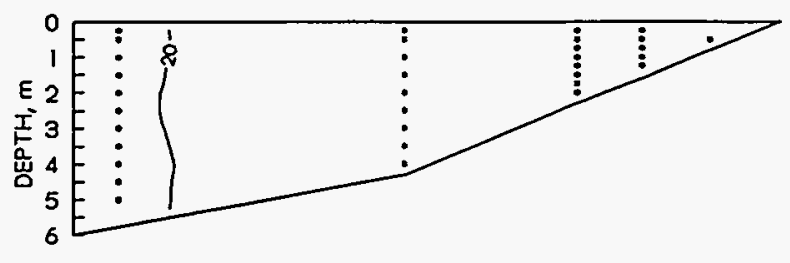

$11 / 01 / 91-2000$

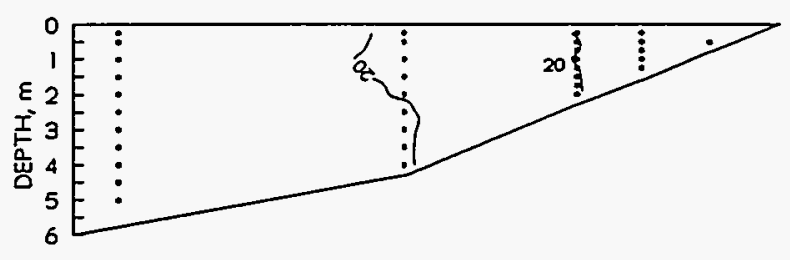

$11 / 02 / 91-0000$

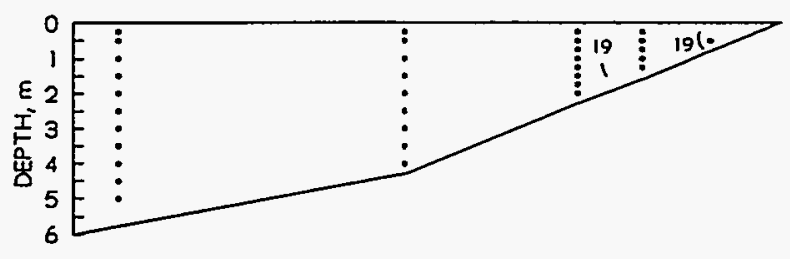

$11 / 02 / 91-0400$

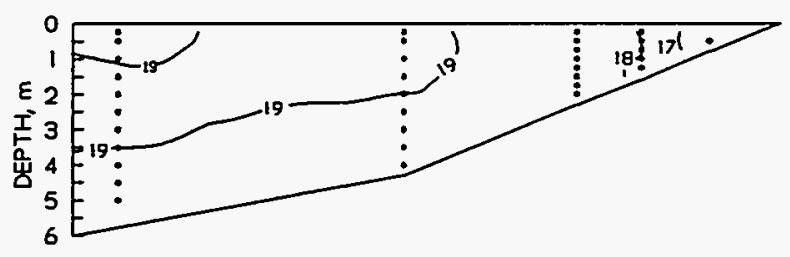

$11 / 02 / 91-0800$

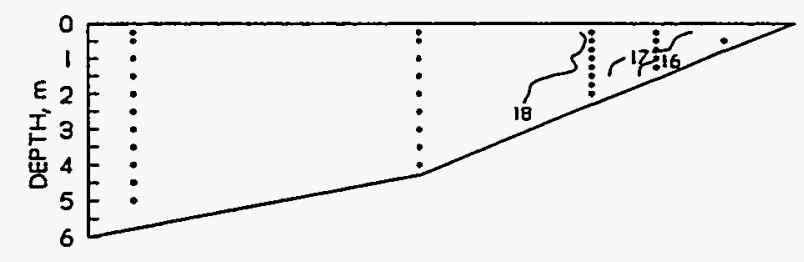


riguie is. Iemperature patterns aiong ine central transect ouring $\mid$ yy $\mid$ wnicn represent the final seeds of the six temperature clusters selected by FastClus. Temperatures are indicated as deviations (in $\mathrm{C}^{\circ}$ ) from the water temperature at the $5.0 \mathrm{~m}$ depth of Station 8. Asterisks show the locations of temperature sensors.

- STRONG COOLING OF SHALLOW AREAS, MIMIMAL THERMAL STRATIFICATION
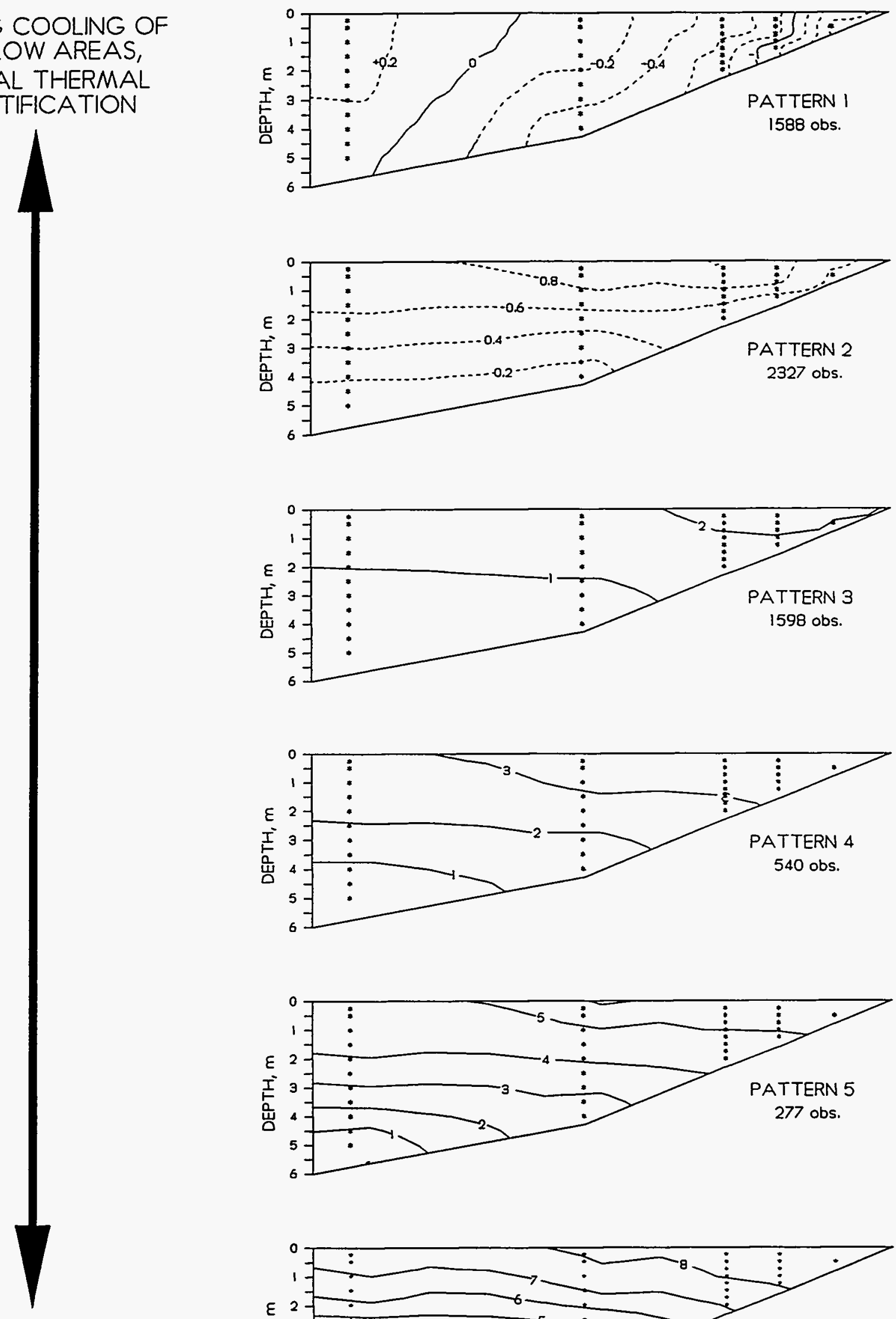

STRONG HEATING OF SHALLOW AREAS, MAXIMAL THERMAL STRATIFICATION

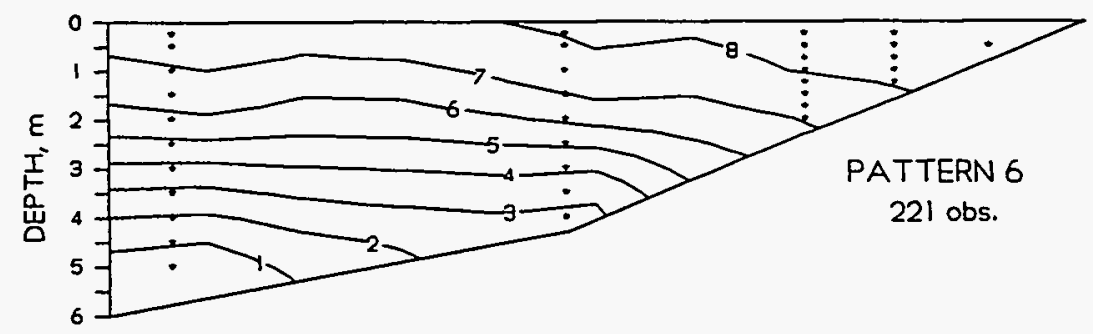


stations) and the underflow of cooler water at stations 5,6 and 7. Stratification increases with increasing pattern number. Intermediate numbered patterns le.g., 2, 3 and 4) may result from either heating of lower numbered patterns or cooling of higher numbered ones. The two patterns showing the greatest stratification ( 5 and 6) occurred only after periods of surface heating in the spring and early summer (May through early July), when relatively cool water was present at the bottom of the deeper stations. Other patterns occurred throughout most of the period of measurement.

Daily heating and cooling were sufficient to produce marked alterations in temperature stratification within the embayment during most 24-hour periods. Eighty-seven percent of the 24-hour periods examined included observations that fell into two or more temperature stratification patterns (Table 2). Half of the dates when a single pattern persisted for 24 hours occurred in November, when the water column was cooling and often nearly isothermal. On most of these dates temperatures fell into pattern 1.

Wind velocity affected the development of vertical temperature gradients. On calm, sunny days steep vertical temperature gradients formed near the surface at all but the shallowest stations. Daytime vertical temperature gradients were typically greatest between 1330 and 1630 . The depth of the late afternoon (1600 hours) mixed layer increased with increasing wind velocity. On very calm days the late-afternoon mixed depth was sometimes only $0.25 \mathrm{~m}$ or less, while on windy days deeper stations were mixed to the bottom. The depth of the mixed layer at 
TABLE 2. Number of temperature patterns occurring daily (midnight to midnight) during 1991.

\begin{tabular}{|c|c|c|}
\hline $\begin{array}{c}\text { Number } \\
\text { of } \\
\text { Patterns }\end{array}$ & $\begin{array}{c}\text { Number of } \\
\text { Days }\end{array}$ & Percent \\
\hline \hline 1 & 17 & 13 \\
\hline 2 & 77 & 57 \\
\hline 3 & 40 & 29 \\
\hline 4 & 1 & 1 \\
\hline
\end{tabular}


the outermost station (Station 8) was more highly correlated with the average wind velocity over the eight hours preceding the measurement (i.e., 0800-1600) than with averages over shorter or longer periods (Figure 14). Theoretically, wind stress is approximately proportional to the square of wind velocity (Hutchinson 1957), but correlations between the daily mixed depth and the square of average wind velocity were weaker than those with average wind velocity. Development of the daily mixed layer occurred essentially independently each day, as shown by the very weak correlation with the mixed depth from the previous day $\left(r^{2}=0.131\right.$, $N=134)$.

Horizontal temperature gradients were also influenced by wind velocity. As with vertical gradients, horizontal gradients were disrupted by strong winds. The daily maximum horizontal temperature difference at the surface $(0.25 \mathrm{~m}$ depth) between Stations 5 and 8 was negatively correlated with wind velocity. The strongest correlation between the intensity of the gradient and wind $1 r^{2}=0.244$, $N=138, P<0.01)$ was with the average wind velocity on the previous day. Effects of past conditions were slow to dissipate, as shown by the relatively strong positive correlation $\left(r^{2}=0.409, N=138, P<0.01\right)$ of the horizontal temperature difference with that from the previous day.

Effects of wind direction on the development of vertical and horizontal temperature gradients were generally non detectable. Correlations between the mixed depth or the horizontal temperature gradient strength and the vector 


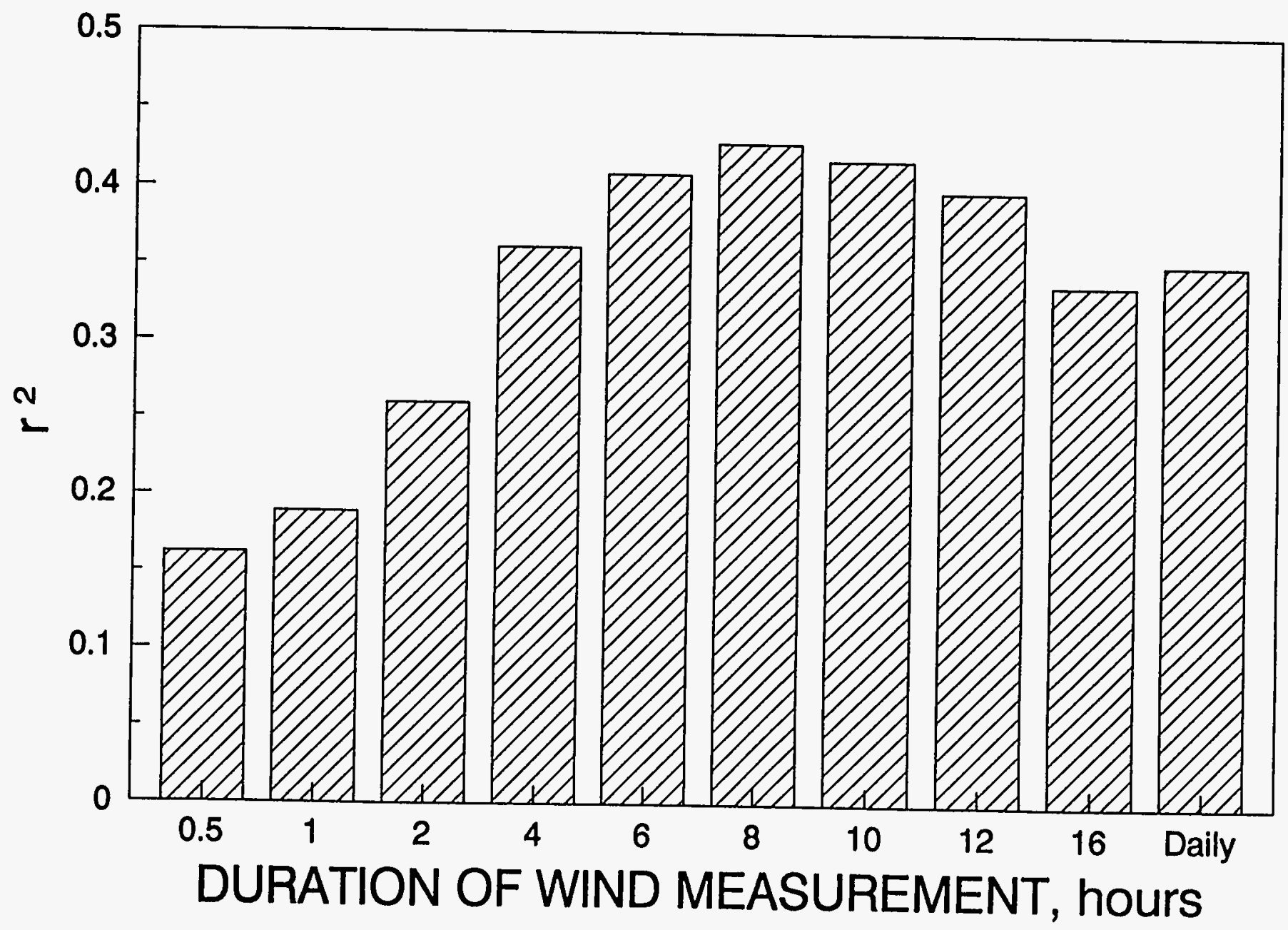

Figure 14. Strength of the correlation between the depth of the late-afternoon (1600 hours) surface mixed layer and wind velocity, averaged over varying periods prior to 1600 . 
components of the wind along the transect and perpendicular to it were weak and generally not significant $(P \geq 0.05)$.

\subsection{Dye Movement}

Temperatures measured during the night of October 15 and the morning of October 16 (Figure 15) indicate considerable nighttime cooling with an apparent underflow of cooler water at the central stations from 0800 through 1200 on October 16. Dye from the October 16 injection was initially distributed throughout the water column, with highest concentrations at 1.0 and $1.25 \mathrm{~m}$ depths (Figure 16). Movement of the dye cloud along the central transect (Figure 17) was towards shore in near-surface layers (from approximately 0 to $1.25 \mathrm{~m}$ ) and away from shore in deeper layers $(1.5 \mathrm{~m}$ and deeper). Average velocities of the dye cloud strata along the central transect, as measured by the movement of their centers of mass during the study (Figure 18), were $.45 \mathrm{~cm} / \mathrm{sec}$ at the surface and $.63 \mathrm{~cm} / \mathrm{sec}$ near the bottom. Winds during the study deflected surface water to and along the northwestern shore of the embayment (Figure 19). By the end of the study, a portion of the surface dye cloud had swept back across the central transect, where it appeared as a separate dye cloud near the surface at Station 6 and beyond (see Figures 17 and 18). 
Figure 15. Water temperatures measured prior to and during the October dye study.
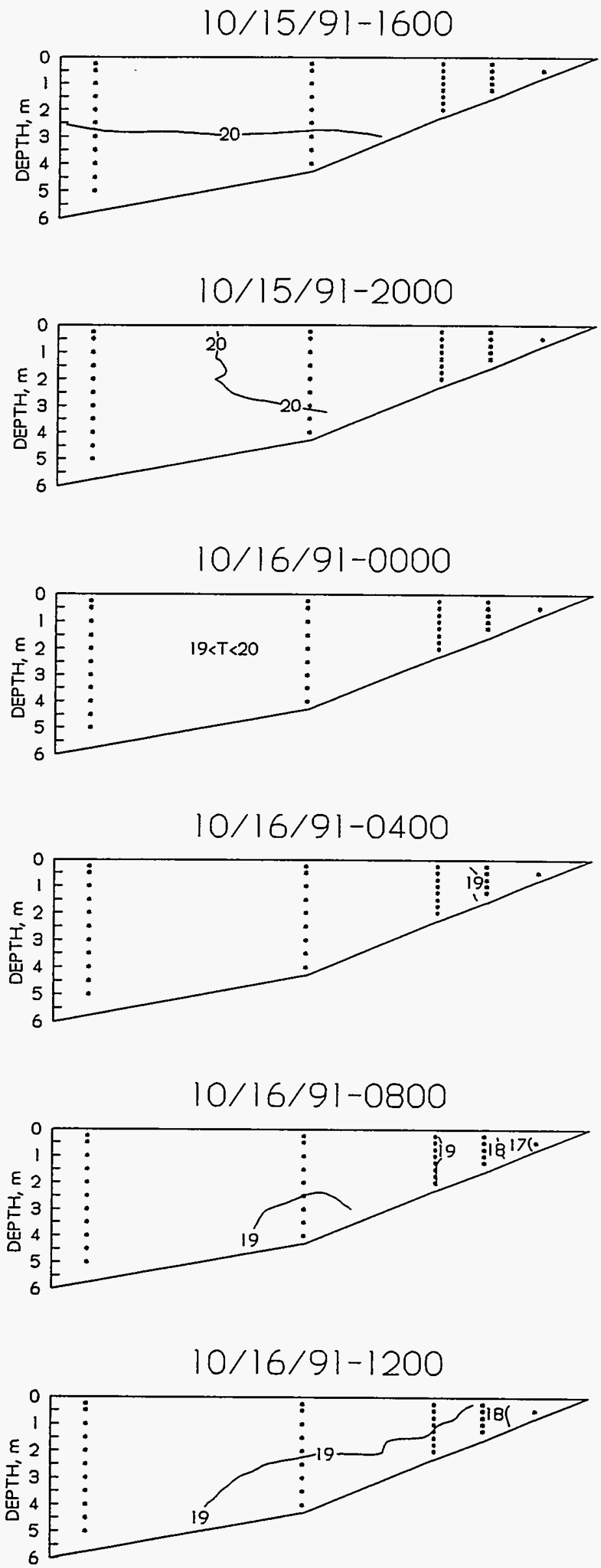


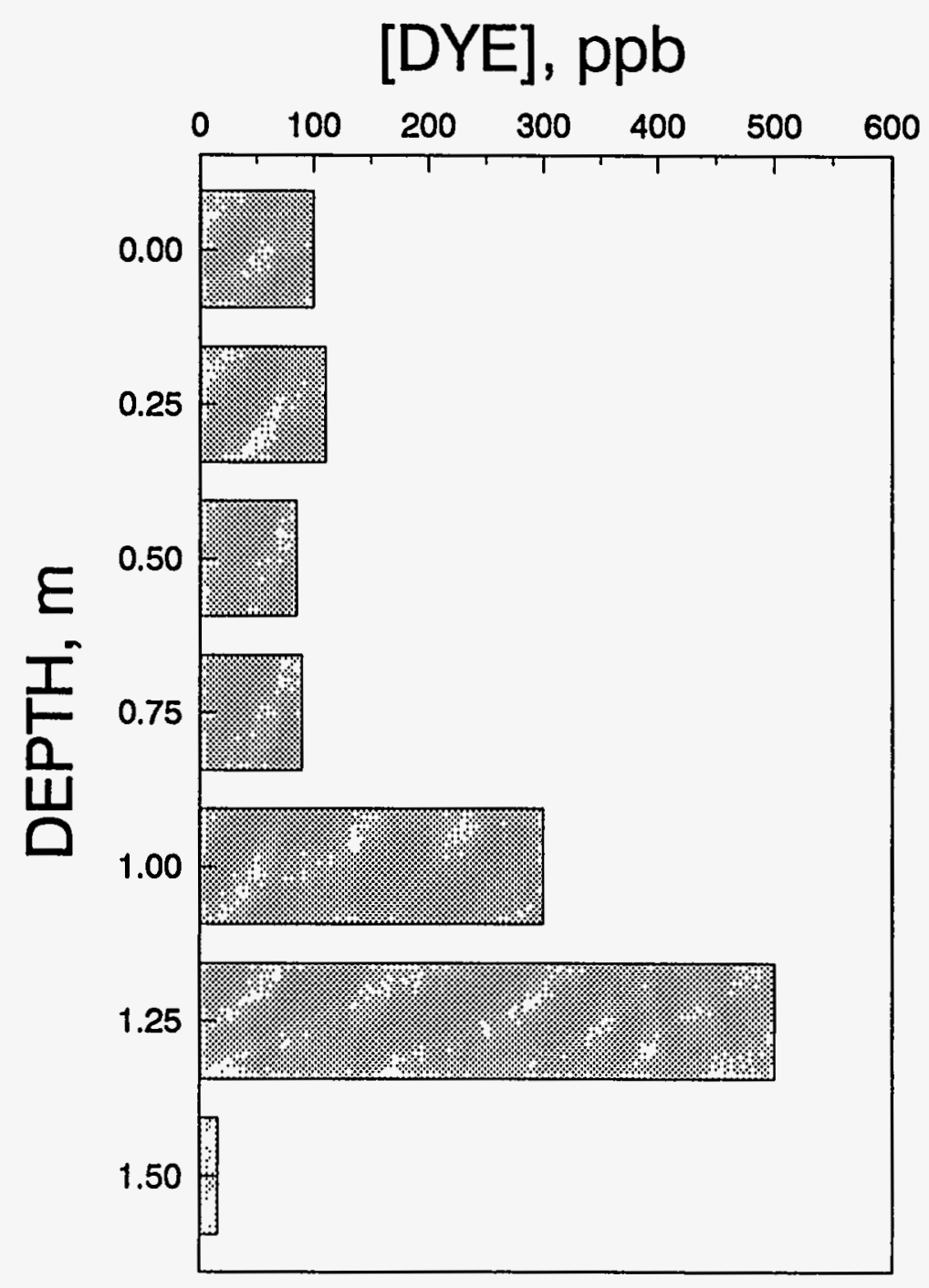

Figure 16. Initial depth distribution of dye during the study conducted 16 October 1991. 
Figure 17. Movement of the dye cloud along the central transect, 16 October 1991.
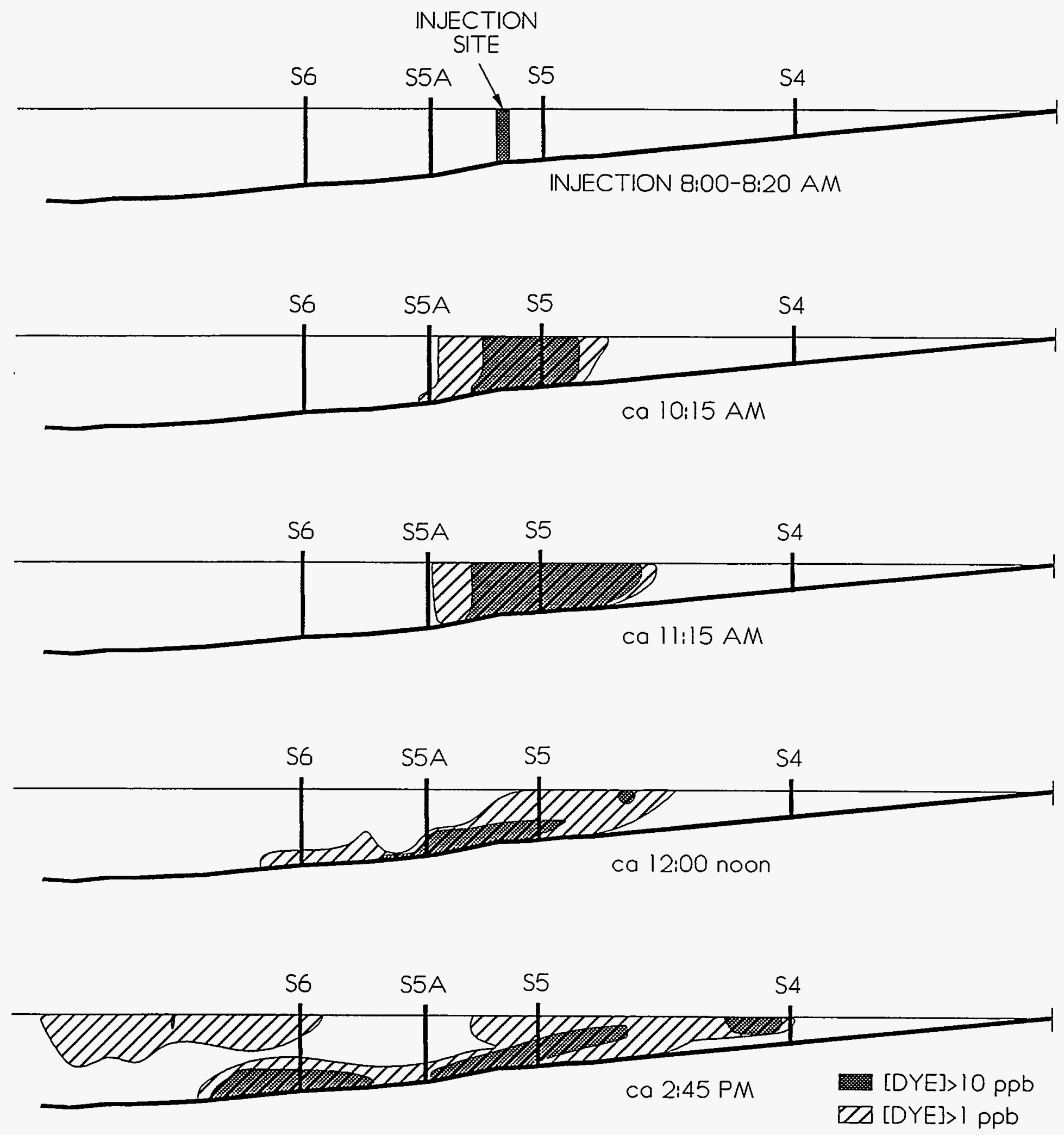
Figure 18. Movement of the centers of mass of dye cloud strata along the central transect, 16 October 1991. Each point indicates the position of the center of mass of the dye cloud in the indicated depth stratum.
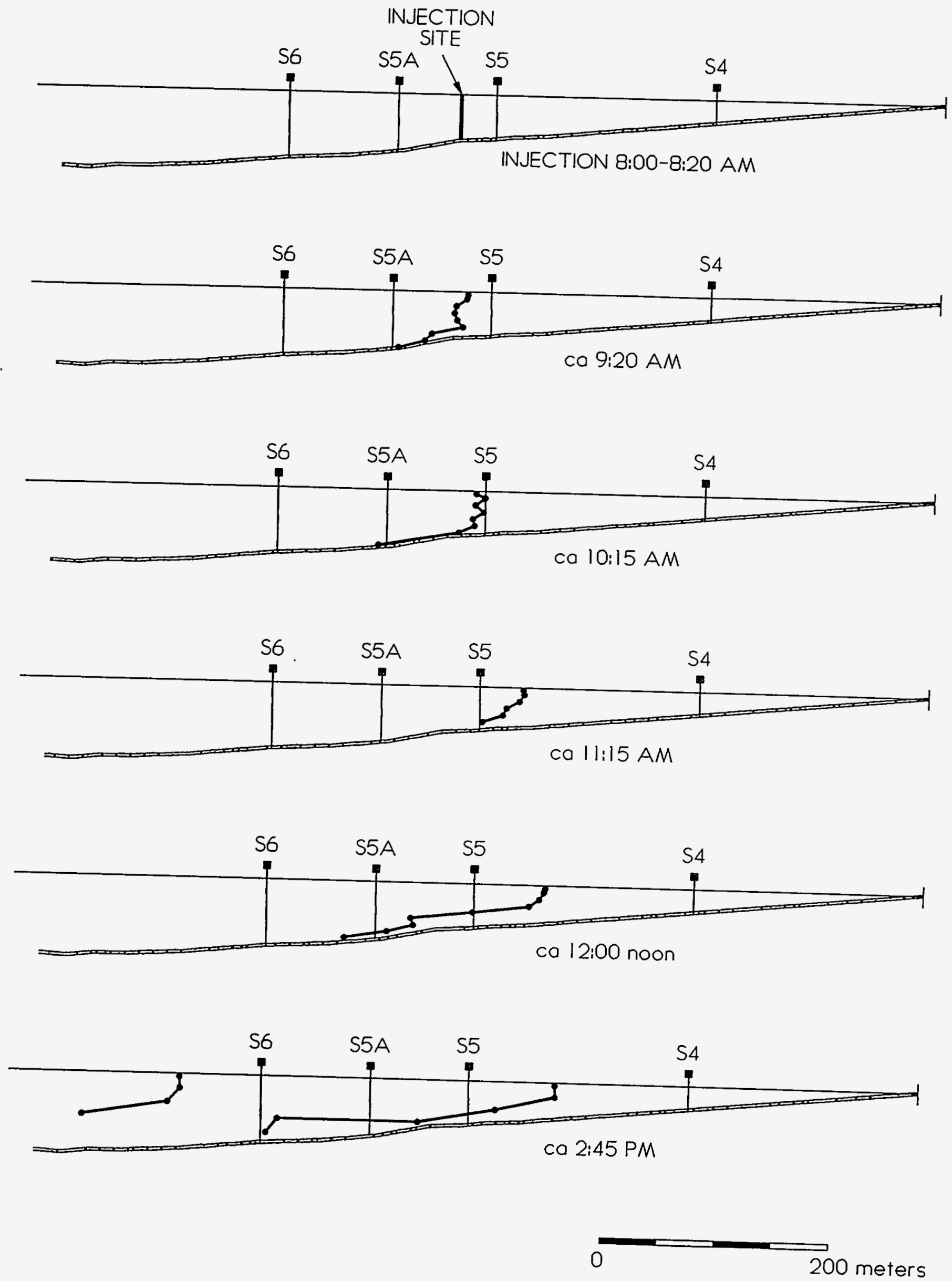
Figure 19. Movement of the surface dye cloud and wind direction and velocity during the morning and early afternoon of 16 October 1991. Each wind arrow indicates the average direction and magnitude of surface winds during the 30 minute period ending at the indicated time. See Figure 5 for an explanation of the wind indicators.

Minky Cove

16 OCT 9I DYE INJECTION
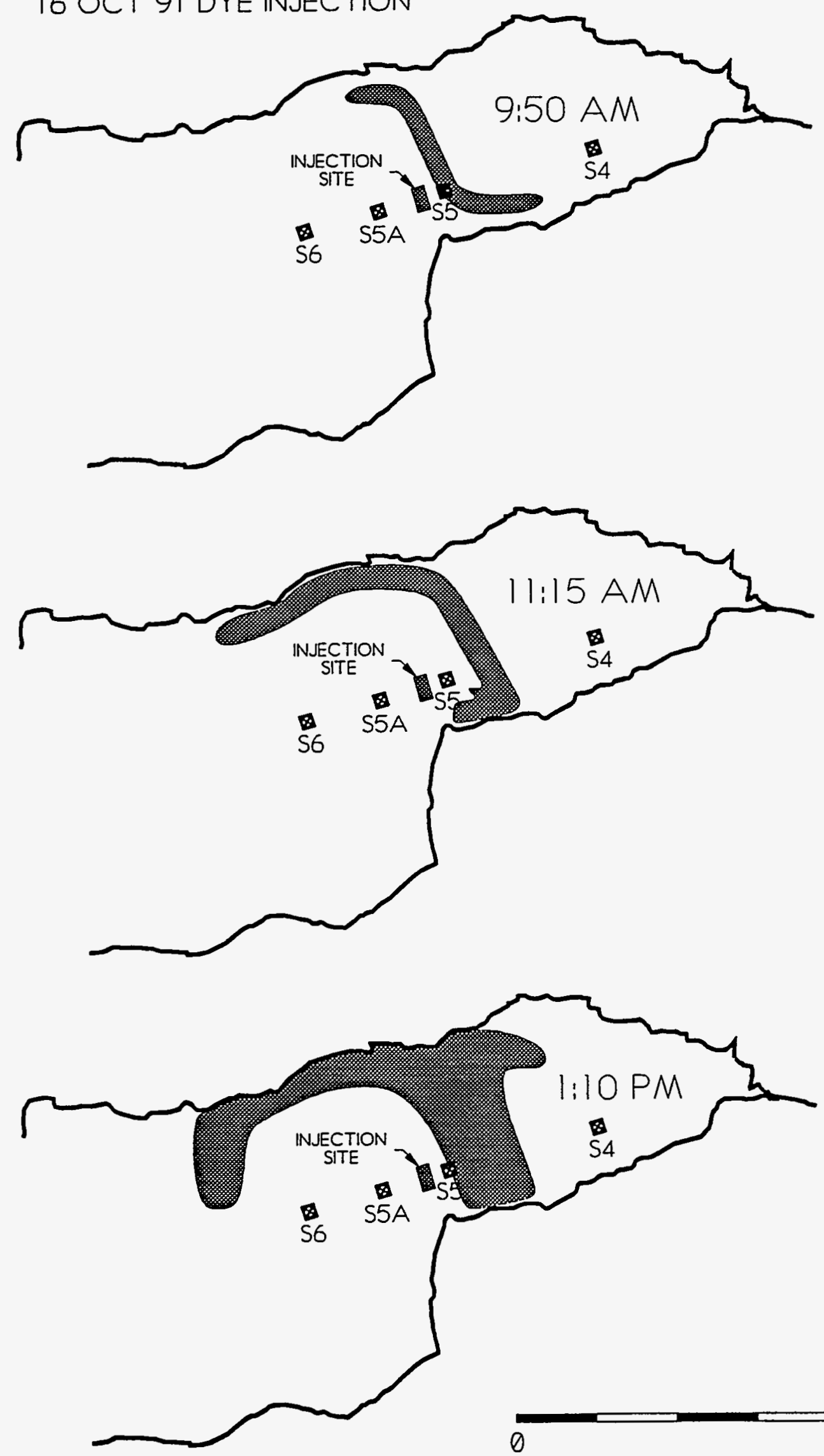

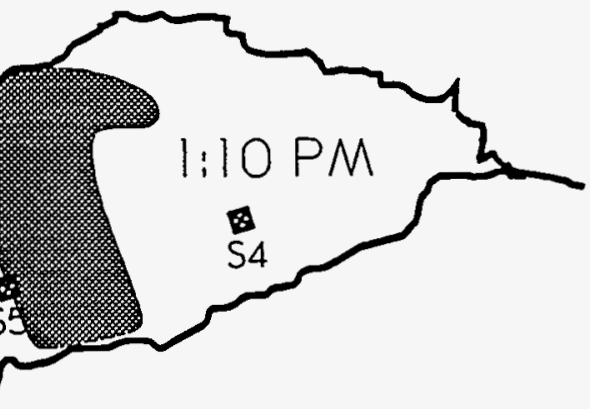

\section{0:00-11:00 AM}

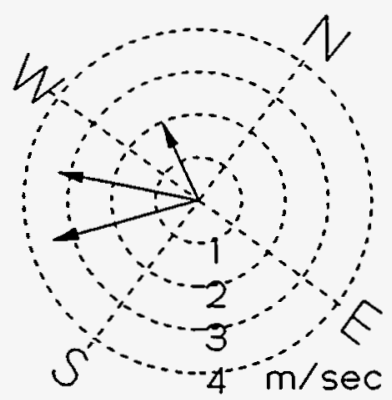

11:30 AM-1:00 PM

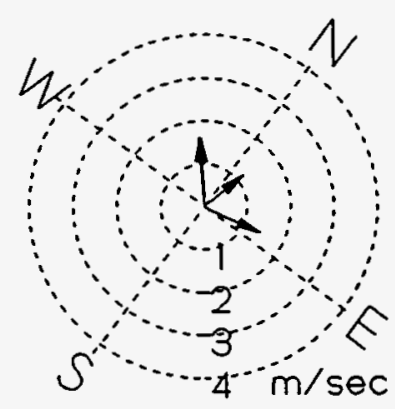




\subsection{Discussion}

Differential heating and cooling of the water column occurred on a diel basis nearly every day during the study period, indicating that convective circulation is potentially a very important hydraulic exchange mechanism in the Minky Creek embayment. Heating and cooling were often sufficient to greatly alter vertical and horizontal temperature gradients, as shown by regular shifts between temperature patterns during most 24-hour periods.

On sunny days, heating of surface water typically produced very strong thermal gradients. Shallow areas often became much warmer than even the surface layers at deeper locations. Substantial heating often extended to the bottom in shallow areas, though it was restricted to relatively shallow layers in deeper areas. Wind disrupted vertical stratification and deepened the surface mixed layer. On calm days, temperature gradients of $1^{\circ} \mathrm{C} / \mathrm{m}$ or greater developed within $0.25 \mathrm{~m}$ of the surface. On windy days such vertical temperature gradients were absent from most or all stations. The depth of the late afternoon (1600) mixed layer was related most strongly to winds over the previous 8 hours, or approximately the length of the daytime heating period.

Compared with vertical gradients, horizontal gradients develop over much greater distances and integrate past conditions over a longer time scale. Where the vertical extent of the late afternoon mixed layer was determined by conditions during the day of measurement, the intensity of horizontal temperature gradients 
was at least partially determined by temperature gradients and winds from the previous day.

Convective circulation typically lags behind the heating and cooling that produce it, due to the inertia of the water masses involved (Monismith et al. 1990). Thus, circulation produced by heating continues well into the night, and circulation produced by cooling continues into the afternoon. Dye injection results illustrate the persistence of circulation produced by nighttime cooling, which was still evident in the movement of dye masses at 1400 .

Results of the dye tracer experiment also illustrate the complex, threedimensional circulation patterns produced by the combined effects of convection and wind. Convection-driven circulation, driven by night-time cooling, moved surface water towards shore and deeper water outward along the bottom of the embayment. Surface water layers were also influenced by wind and responded rapidly to changes in wind direction. Wind moved surface layers laterally along the periphery of the embayment and eventually outward towards the mouth of the bay. Overall this wind-driven dye mass moved outward at velocities exceeding those produced by convection.

Differential heating promotes water circulation primarily in the upper 2-3 m of the water column, due to warm surface flows that develop when there is a relatively shallow mixed layer. During differential cooling water moves from shallow regions as underflows and is replaced with a return current of surface water. Thus, convective water circulation is relatively shallow during differential 
heating phases, whereas water located near the surface during the day potentially moves to the bottom of the embayment at night during differential cooling phases. These fundamentally different circulation patterns have important implications for the transport and availability of nutrients to phytoplankton communities located in the euphotic zone (James and Barko 1991a, 1991b). They may also play an important role in determining the fate of aquatic herbicides.

We currently do not know how the convective flow velocities measured during the single dye study relate to those that develop under other environmental conditions. Flow velocities appear to be driven by the intensity of horizontal temperature gradients. Linden and Simpson (1986) showed experimentally that under calm conditions, convective flows are generated as a result of a sharpening of horizontal temperature gradients, or frontogenesis, and that turbulence li.e., wind mixing) can arrest or reduce convective flow velocities by disrupting these fronts. Thus, flow velocities may be strongly affected by wind mixing. In addition, it is often difficult to separate wind-generated circulation patterns from those generated by differential heating and cooling on the basis of water temperature alone (i.e., Monismith et al. 1990).

In the absence of wind mixing, factors influencing light extinction, such as turbidity, can strongly affect the development of the mixed surface layer and convective circulation dynamics. Aquatic macrophytes both dampen wind effects and substantially reduce light penetration into the water column, resulting in the development of a very shallow (i.e., $25 \mathrm{~cm}$ or less) surface mixed layer. Shallow 
heat penetration prevents warming of the bottom waters in shallow regions, which may inhibit daytime convective circulation (Imberger and Patterson 1990). Resultant horizontal temperature gradients that develop may therefore provide an insufficient baroclinic pressure gradient (i.e., Monismith et al. 1990) to allow for convective circulation during the day. Since nighttime cooling is penetrative, it may be relatively unaffected in vegetation, or may be stronger because of reduced wind effects. Thus, circulation patterns may be differ significantly between vegetated and unvegetated areas. 


\section{Acknowledgments}

Mr. Harry Eakin, Mr. Kevin Pigott, Mr. Douglas Murphy, and Mr. David Brewster are gratefully acknowledged for construction and deployment of the platforms, maintenance of thermistor stations, and assistance with dye studies.

Mr. R. Michael Stewart and Mr. Michael L. Schneider contributed helpful criticism of the report. 


\section{Literature Cited}

Hutchinson, G. E. 1957. A treatise on limnology. Volume 1. Geography, physics and chemistry of lakes. Wiley, New York.

Imberger, J., and J. C. Patterson. 1990. Physical limnology. Advances in Applied Mechanics 27:303-475.

James, W. F. 1991. Convective circulation during differential heating and cooling in the minky creek embayment of Guntersville Reservoir, Alabama: Data summary for 1991 .

James, W. F., and J. W. Barko. 1991a. Estimation of phosphorus exchange between littoral and pelagic zones during nighttime convective circulation. Limnology and Oceanography 36:179-187.

James, W. F. and J. W. Barko. 1991b. Littoral-pelagic phosphorus dynamics during nighttime convective circulation. Limnology and Oceanography 36:249-260.

Linden, P. F., and J. E. Simpson. 1986. Gravity driven flows in a turbulent fluid. Journal of Fluid Mechanics 172:481-497.

Monismith, S., J. Imberger, and M. Morison. 1990. Convective motions in the sidearm of a small reservoir. Limnology and Oceanography 35:1676-1702.

SAS Institute Inc. 1988. SAS/STAT ${ }^{\circ}$ user's guide, Release 6.03 edition. SAS Institute Inc., Cary, North Carolina.

Stefan, H. G., G. M. Horsch, and J. W. Barko. 1989. A model for the estimation of convective exchange in the littoral region of a shallow lake during cooling. Hydrobiologia 174:225-234. 
Figure Captions

Figure 1. Induction of convective water movements in shallow embayments by differential heating and cooling of the shallows.

Figure 2. Location of Guntersville Reservoir and the Minky Creek Embayment.

Figure 3. Locations of temperature monitoring stations during 1991.

Figure 4. Hourly air and water surface (at the outermost station) temperatures during 1991.

Figure 5. Distribution of daily average wind direction and velocity, 1991. Arrows point in the direction of air movement (i.e. away from the source of the wind) and arrow length is proportional to daily average wind velocity.

Figure 6. Temperature patterns along the central transect at four-hour intervals on May 29 and 30, 1991. Asterisks show the locations of temperature sensors.

Figure 7. Temperature patterns along the central transect at four-hour intervals on June 7 and 8, 1991. Asterisks show the locations of temperature sensors.

Figure 8. Temperature patterns along the central transect at four-hour intervals on July 28 and 29, 1991. Asterisks show the locations of temperature sensors.

Figure 9. Temperature patterns along the central transect at four-hour intervals on August 19 and 20,1991. Asterisks show the locations of temperature sensors.

Figure 10. Temperature patterns along the central transect at four-hour intervals on September 13 and 14, 1991. Asterisks show the locations of temperature sensors.

Figure 11. Temperature patterns along the central transect at four-hour intervals on October 14 and 15, 1991. Asterisks show the locations of temperature sensors.

Figure 12. Temperature patterns along the central transect at four-hour intervals on November 1 and 2,1991. Asterisks show the locations of temperature sensors. 
Figure 13. Temperature patterns along the central transect during 1991 which represent the final seeds of the six temperature clusters selected by FastClus. Temperatures are indicated as deviations (in $\mathrm{C}^{\circ}$ ) from the water temperature at the $5.0 \mathrm{~m}$ depth of Station 8 . Asterisks show the locations of temperature sensors.

Figure 14. Strength of the correlation between the depth of the late-afternoon (1600 hours) surface mixed layer and wind velocity, averaged over varying periods prior to 1600 .

Figure 15. Water temperatures measured prior to and during the October dye study.

Figure 16. Initial depth distribution of dye during the study conducted 16 October 1991.

Figure 17. Movement of the dye cloud along the central transect, 16 October 1991.

Figure 18. Movement of the centers of mass of dye cloud strata along the central transect, 16 October 1991. Each point indicates the position of the center of mass of the dye cloud in the indicated depth stratum.

Figure 19. Movement of the surface dye cloud and wind direction and velocity during the morning and early afternoon of 16 October 1991. Each wind arrow indicates the average direction and magnitude of surface winds during the 30 minute period ending at the indicated time. See Figure 5 for an explanation of the wind indicators. 